\title{
Adapted ECC ozonesonde for long-duration flights aboard boundary-layer pressurised balloons
}

\author{
François Gheusi $^{1}$, Pierre Durand ${ }^{1}$, Nicolas Verdier ${ }^{2}$ François Dulac $^{3}$, Jean-Luc Attié ${ }^{1,4}$, Philippe Commun ${ }^{5}$, \\ Brice Barret $^{1}$, Claude Basdevant ${ }^{6}$, Antoine Clenet ${ }^{2}$, Solène Derrien ${ }^{1}$, Alexis Doerenbecher ${ }^{4}$, Laaziz El Amraoui ${ }^{4}$, \\ Alain Fontaine ${ }^{7}$, Emeric Hache ${ }^{1,4}$, Corinne Jambert ${ }^{1}$, Elodie Jaumouillé ${ }^{2,4}$, Yves Meyerfeld ${ }^{1}$, Laurent Roblou ${ }^{1}$, and \\ Flore Tocquer $^{1}$ \\ ${ }^{1}$ Laboratoire d'Aérologie, University of Toulouse, CNRS, UPS, Toulouse, France \\ ${ }^{2}$ Centre National d'Études Spatiales, Toulouse, France \\ ${ }^{3}$ Laboratoire des Sciences du Climat et de l'Environnement, IPSL-LSCE, CEA/CNRS/UVSQ, \\ Gif-sur-Yvette, France \\ ${ }^{4}$ CNRM-GAME, Météo-France/CNRS UMR 3589, Toulouse, France \\ ${ }^{5}$ ALTEN, Toulouse, France \\ ${ }^{6}$ Laboratoire de Météorologie Dynamique, University Pierre et Marie Curie/Ecole Poytechnique/ \\ Ecole Normale Supérieure de Paris/CNRS, Paris, France \\ ${ }^{7}$ Observatoire Midi-Pyrénées, University of Toulouse/CNRS, Toulouse, France \\ Correspondence to: François Gheusi (francois.gheusi@aero.obs-mip.fr)
}

Received: 16 November 2015 - Published in Atmos. Meas. Tech. Discuss.: 2 February 2016

Revised: 21 October 2016 - Accepted: 28 October 2016 - Published: 5 December 2016

\begin{abstract}
Since the 1970s, the French space agency CNES has developed boundary-layer pressurised balloons (BLPBs) with the capability to transport lightweight scientific payloads at isopycnic level and offer a quasi-Lagrangian sampling of the lower atmosphere over very long distances and durations (up to several weeks).

Electrochemical concentration cell (ECC) ozonesondes are widely used under small sounding balloons. However, their autonomy is limited to a few hours owing to power consumption and electrolyte evaporation. An adaptation of the ECC sonde has been developed specifically for long-duration BLPB flights.

Compared to conventional ECC sondes, the main feature is the possibility of programming periodic measurement sequences (with possible remote control during the flight). To increase the ozonesonde autonomy, the strategy has been adopted of short measurement sequences (2-3 min) regularly spaced in time (e.g. every $15 \mathrm{~min}$ ). The rest of the time, the sonde pump is turned off.

Results of preliminary ground-based tests are first presented. In particular, the sonde was able to provide cor-
\end{abstract}

rect ozone concentrations against a reference UV-absorption ozone analyser every $15 \mathrm{~min}$ for 4 days.

Then we illustrate results from 16 BLBP flights launched over the western Mediterranean during three summer field campaigns of the ChArMEx project (http://charmex.lsce.ipsl. fr): TRAQA in 2012, and ADRIMED and SAFMED in 2013. BLPB drifting altitudes were in the range $0.25-3.2 \mathrm{~km}$. The longest flight lasted more than $32 \mathrm{~h}$ and covered more than $1000 \mathrm{~km}$. Satisfactory data were obtained when compared to independent ozone measurements close in space and time. The quasi-Lagrangian measurements allowed a first look at ozone diurnal evolution in the marine boundary layer as well as in the lower free troposphere. During some flight segments, there was indication of photochemical ozone production in the marine boundary layer or even in the free troposphere, at rates ranging from 1 to $2 \mathrm{ppbv} \mathrm{h}^{-1}$, which is slower than previously found in the boundary layer over land in the same region. 


\section{Introduction}

The Chemistry-Aerosol Mediterranean Experiment (ChArMEx; http://charmex.lsce.ipsl.fr) project aims at an updated assessment of the Mediterranean atmospheric environment. The Mediterranean troposphere is indeed particularly rich in aerosol and ozone, especially during the long Mediterranean dry summer season when concentrations are higher over the basin than over most of continental Europe (e.g. Cuesta et al., 2013; Nabat et al., 2013). In this context, experimental campaigns including airborne observations were performed in summer 2012 and 2013 in order to document the export of continental air masses over the basin and their chemical evolution. The present article focuses more specifically on the set-up of, and first results from, drifting balloons carrying ozonesondes that were deployed during those campaigns to perform Lagrangian observations of ozone concentration in the low troposphere over the basin, following the former experience of Bénech et al. (2008) with shorter duration balloons.

The Lagrangian approach in fluid mechanics considers variables in a frame of reference that moves with the fluid. This is a natural approach for dealing with gas phase chemistry in the atmosphere (Businger et al., 1996, 2006). A Lagrangian volume - hereafter a parcel - is a volume of air sufficiently small to be coherently transported by the local wind and be considered (in first order approximation) as isolated from its environment (that is, no or reduced mass exchange occurs through its boundaries). Thus, a Lagrangian air parcel can be viewed as a "smog chamber without walls" (Businger et al., 1996).

A constant-volume balloon (hereafter CVB) is generally made of a rigid pressurised envelope inflated with a mixture of helium and air, so that the lift balances the balloon weight at a given air density level. A CVB is thus drifting at nearly zero horizontal velocity relative to ambient air. Under well-chosen conditions with negligible vertical air motion across density levels, constant-volume balloons offer a method of performing quasi-Lagrangian measurements in the atmosphere. CVBs have been used as Lagrangian tracers as early as in the 1950s. A first use of Lagrangian balloons for comparison of turbulence with Eulerian tower-based observations was reported by Gifford (1955). Businger et al. (1996, 2006) have reviewed the use of CVB in atmospheric research since that time and have also discussed their limitations as Lagrangian markers. We only briefly recall different types of use here.

CVBs have been intensively used as simple trajectory markers to document airflows. For instance, positions from five balloons released together at the same density level can be used to derive the full kinematics of the flow: divergence, vorticity and shear and stretching deformations (Businger et al., 2006). During the AUTAN 84 field campaign, CVB trajectories were used to build an interpolated wind field, the horizontal divergence and vorticity of which were derived and analysed in relation to orographic forcing (Bénech et al., 1987a, b; Durand et al., 1993). CVB trajectories launched during the PYREX campaign (held in 1990) evidenced trapped lee waves downwind of the Pyrenees (Caccia et al., 1997). CVB trajectories were simulated in a mesoscale model through the implementation of an equation describing the balloon response to the vertical wind. This allowed a direct assessment of the model performance by comparing the simulated and observed CVB trajectories, thus coping with the non-Lagrangian character of the balloon along the vertical (Koffi et al., 2000).

With the view to measure the chemical evolution of a Lagrangian air parcel, two strategies are possible: (i) using a CVB as a Lagrangian marker, thus as a target for a research aircraft operating measurements close to the balloon at repeated instants; (ii) directly using the CVB as conveyor for on-board sensors.

The first strategy was used for instance in several Lagrangian experiments during the ASTEX/MAGE (1992) ACE-1 (1995), ACE-2 (1997) and ICARTT (2004) airborne campaigns, enabling the calculation of chemical budgets and aerosol studies in the marine boundary layer (Businger et al., 1996, 2006, and references therein).

The second strategy (on-board sensors) might be difficult to carry out for atmospheric gaseous chemistry and aerosol studies, because sensors with sufficient accuracies (e.g. those used aboard research aircraft) are generally either too heavy to be transported by small balloons or too expensive to be lost. Only a few types of lightweight and reasonably inexpensive sensors exist that are suitable for balloon-borne measurements.

Apart from water vapour, ozone is probably the gas which is most frequently observed with balloons. It has been measured worldwide on a regular basis since the 1970s with small sounding balloons and electrochemical sensors, e.g. in the frame of the GAW, SHADOZ and NDACC networks (Staehelin, 2008; GAW ASOPOS panel, 2011). A more experimental alternative was a light UV-absorption sensor specifically designed for balloon flights, which was carried out during ICARTT aboard CVB (Businger et al., 2006; Mao et al., 2006).

The most frequently used ozone sensors for balloon flights are based on the principle of fast reaction of ozone with iodide ions within an electrochemical cell. Three types of electrochemical ozonesondes exist: the electrochemical concentration cell (ECC), the carbon iodine cell, and the BrewerMast sonde (GAW ASOPOS panel, 2011, and references therein). In this study, we focus on the ECC type, which is in use in about $80 \%$ of the stations of the worldwide WMO/GAW ozone sounding network. The total weight of the flight package is about $1 \mathrm{~kg}$. Therefore, ECC ozonesondes are suitable for tropospheric flights aboard small CVBs. The lifetime of standard ECC sondes is, however, limited by power consumption but also by electrolyte evaporation. For a pump flow rate of $200 \mathrm{~mL} \mathrm{~min}^{-1}$ (usual value), Komhyr 
(1969) indicated a loss rate of about $0.2 \mathrm{mLh}^{-1}$ (at $25^{\circ} \mathrm{C}$, $50 \%$ humidity and sea level pressure). At this rate, the $3 \mathrm{~mL}$ cathode chamber of an ECC sonde would be emptied within $15 \mathrm{~h}$, but in reality, the sonde performance lowers well before this time because the ozone measurement is to some extent sensitive to the electrolyte concentration (see e.g. Smit et al., 2007, and also the discussion in Sect. 3.2).

Bénech et al. (2008) carried out standard ECC ozonesondes aboard CVB for up to $6 \mathrm{~h}$ flights in the boundary layer and the lower free troposphere during two ESCOMPTE field campaigns in 2000 and 2001, taking place on the French Mediterranean coast (Cros et al., 2004) ${ }^{1}$. From flight segments during which the balloons remained in the same homogeneous air mass, the authors were able to quantify quasiLagrangian ozone growth rates due to photoproduction in the polluted summer boundary layer, ranging from 0 to $13 \mathrm{ppbv} \mathrm{h}^{-1}$ around a mean value of $6 \mathrm{ppbv} \mathrm{h}^{-1}$.

As early as in the 1970s, the French space agency CNES (Centre National d'Études Spatiales) developed constantvolume balloons for long-range scientific flights in the boundary layer or the low troposphere called "boundarylayer pressurised balloons", hereafter BLPBs (Cadet et al., 1975, 1981; Ethé et al., 2002; Doerenbecher et al., 2016, details on the recent generation of BLPB are also given below). The use of satellite data transmission allows for flights over several days or even weeks. Clearly, standard ECC ozonesondes are not suited for such long-duration flights. Concerning power consumption, the ozonesonde lifetime can be considerably increased by use of high-performance lithium batteries. In spite of this, the issue of electrolyte evaporation remains. A continuously working ECC ozonesonde would not be able to cover a complete ozone diurnal cycle.

For this reason, we present a specific adaptation of ECC ozonesondes in this article, whereby the sonde alternates between short working periods and longer quiescence periods in order to save electrolyte and increase the sonde lifetime up to several days. All technical details are given in Sect. 2. Laboratory tests presented in Sect. 3 were preliminary to flights aboard BLPB during three field campaigns in the western Mediterranean during summer 2012 and 2013. The flights are detailed in Sect. 4. The main results are summarised in the concluding Sect. 5 .

\section{ECC ozonesonde and specific adaptations}

In all our experiments, we used commercial En-Sci Z ECC ozonesondes $^{2}$, either in their original form for conventional balloon soundings or in a specific implementation for flights

\footnotetext{
${ }^{1}$ Note that in 2000-2001, radio transponders were used for data transmission. Thus, the balloon range was also limited by radio transmission, despite the deployment of a regional network of radio receivers during the campaigns.

${ }^{2}$ Now manufactured by Droplet Measurements Technologies, Colorado, USA.
}

aboard CNES constant-volume balloons. In the latter case, only a few elements of commercial En-Sci Z sondes were kept (Sect. 2.2.2).

\subsection{ECC ozonesonde general features}

ECC ozonesondes developed by Komhyr (1969) are among the most commonly used worldwide for tropospheric and stratospheric ozone soundings (Smit et al., 2007; GAW ASOPOS panel, 2011). Ozone mole fractions $x_{\mathrm{O}_{3}}=P_{\mathrm{O}_{3}} / P(P$ being ambient pressure and $P_{\mathrm{O}_{3}}$ ozone partial pressure) are obtained from the sonde data as follows:

$x_{\mathrm{O}_{3}}=\frac{R}{2 F} \frac{T}{P} \frac{I-I_{0}}{Q_{v}}$,

where $R=8.31 \mathrm{~J} \mathrm{~mol}^{-1} \mathrm{~K}^{-1}$ is the universal gas constant, $F=96485 \mathrm{C} \mathrm{mol}^{-1}$ is the Faraday constant, $T$ is the pump temperature, $I$ is the current measured in the ozonesonde, $I_{0}$ is the sonde background current (residual current in absence of ozone) and $Q_{v}$ is the pump volumetric flow rate re $^{3} . T, I$ and $P$ are directly measured on board during the flight, while $I_{0}$ and $Q_{v}$ are derived from pre-flight laboratory measurements. $Q_{v}$ is measured with a soap-film flowmeter, from the time $t_{p}$ needed to fill a control volume $V_{0}=100 \mathrm{~mL}$. $t_{p}$ is usually referred to as the pump time.

The GAW ASOPOS panel (2011) indicates that standard ECC ozonesondes, when operated carefully, have a precision below $5 \%$ and an absolute accuracy below $10 \%$ in the troposphere. They also review the contributions from each instrumental variables in Eq. (1) to the overall uncertainty in great detail (their Fig. 3-1). In the troposphere, it is clearly dominated by the uncertainty on the background current $I_{0}$. The uncertainties of the other variables together contribute less than $1 \%$ of the ozone mole fraction value.

To operate the ECC sondes, we mostly followed the GAW standard procedure detailed in GAW ASOPOS panel (2011). In particular, we applied no altitude correction on the background current value determined from ground measurements. As recommended for En-Sci ECC sondes, we used the "0.5\% half-buffer" cathode solution (Smit et al., 2007; Deshler et al., 2008). For all flights, we charged the ECC sonde chambers with $3 \mathrm{~mL}$ of cathode solution and $1,5 \mathrm{~mL}$ of anode solution.

A few specific adaptations of the GAW standard operation procedure and additional measurements were needed, which are listed below.

The procedure recommends to proceed with the advanced preparation 3-7 days before the flight, which is suited for a single weekly sounding. During the 2012 and 2013 campaigns, intensive observation periods (IOPs) were triggered upon meteorological alert, during which up to six ozonesondes were launched within $24 \mathrm{~h}$. A great number of sondes

\footnotetext{
${ }^{3}$ In Eq. (1), a conversion efficiency $\eta=1$ is taken, which is the usual assumption with the used solutions (Smit et al., 2007; GAW ASOPOS panel, 2011).
} 
thus had to be prepared without visibility on the flight date. Consequently, the advanced preparations were proceeded 2 to 14 days before the flights.

Specific calibration data are available for the 2012 campaign. Measurements were made during the pre-flight preparation phase, whereby the sonde pumped air from an ozone calibrator (Ansyco KT-O3M) with scale points at 1.4, 56 and 106 ppbv. In this case, the values of the background current and pump flow rate used for data processing were adjusted so that the derived ozone mole fractions fit at best the calibrator scale points.

Unfortunately, no such calibration data are available for the 2013 campaigns. Nevertheless, surface ozone mole fraction was continuously measured on the launch site (by means of a TEI 49i UV-absorption ozone analyser). Unlike in 2012, the BLPB ozonesondes worked in continuous mode during the launch and balloon ascent phases, measuring vertical profiles from the ground up to the BLPB ceiling level. In such case, $I_{0}$ was adjusted such that the lowest data point from the ascent profile matches the analyser ozone reading at launch time (Fig. 10). The same was done to processed data from the conventional radiosoundings with ECC ozonesondes also performed during the 2012 and 2013 campaigns.

The only exception was the BLPB flight B55 (in 2013). The ozone data during the launch and ascent phases were obviously not valid (possibly perturbed by very high humidity in the lowest troposphere). Thus, the vertical profile was not used to estimate $I_{0}$, but instead the ground-based measurement of $I_{0}$ during the final preparation phase was retained (as recommended in the GAW procedure).

\subsection{Specific implementation aboard CNES boundary-layer pressurised balloons}

\subsubsection{BLPB overview}

The CNES BLPB consists of a spherical, non-dilatable and pressurised envelope filled with a mixture of helium and air (Fig. 1; Ethé et al., 2002; Doerenbecher et al., 2016). As the balloon volume and mass are constant, the BLPB flies at constant-density (isopycnic) level in the atmosphere. The desired flight level can be adjusted through the total mass of the balloon, by varying the quantity of gas in the balloon (related to internal pressure) or the proportions of air and helium. Two possible diameters exist: 2.5 and $2.6 \mathrm{~m}$. The bigger version is used to reach higher altitudes (2000-3300 m above the launch base).

The data exchange between the balloon and the operation centre is enabled from anywhere on Earth through the Iridium satellite phone connection. This allows for long-range flights (possibly several weeks). In the absence of navigation constraint, the only limitation is the battery autonomy. However, during the 2012 and 2013 campaigns over the western Mediterranean, flights were restricted to a delimited zone over sea and over a number of islands for short transits for

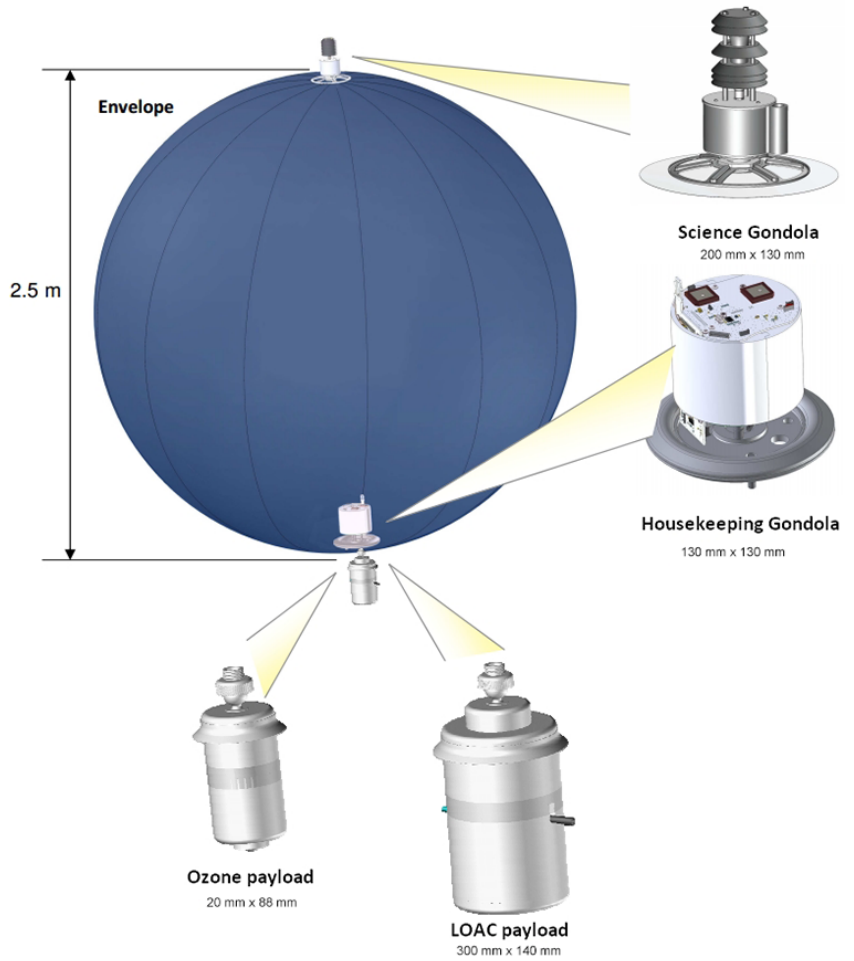

Figure 1. Schematics of a CNES boundary-layer pressurised balloon and its various payloads (2013 version).

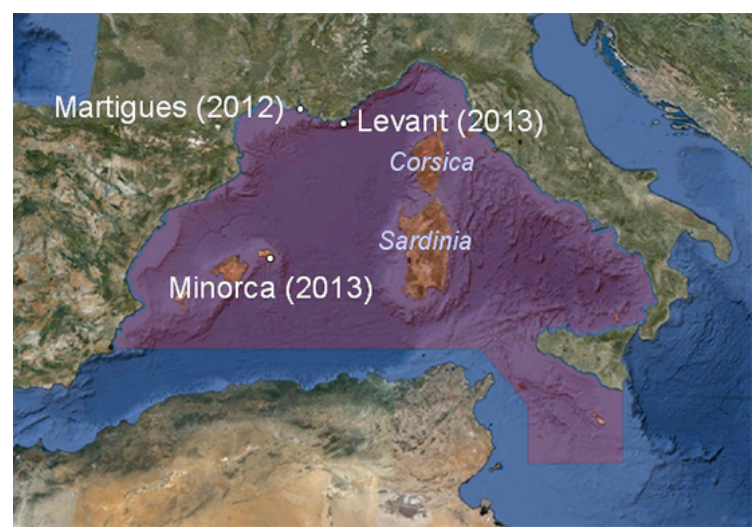

Figure 2. Authorised BLPB flight zone over the western Mediterranean (purple shading) during the campaigns of summer 2013. During the 2012 campaign, flights over the Corsica and Sardinia islands were not yet authorised, the rest of the flight zone being the same. The three launch sites used in 2012 and 2013 (namely Martigues and the Minorca and Levant islands, see Sect. 4) are also indicated in the map.

security reasons (Fig. 2). The flights automatically aborted when the balloons exited from the authorised flight zone (or were aborted upon request from the operation centre). To abort the flight, a heated wire device perforates the envelope. The balloon slowly loses its gas and softly touches down after a few minutes. 
There are three different payloads aboard a BLPB, which are located either at the "north" (upper) or "south" (lower) pole of the balloon (Fig. 1 and Doerenbecher et al., 2016):

- the housekeeping gondola (south pole, inside the envelope) is devoted to navigation control, communication with the other payloads, and remote data transmission and control (plus a redundant GPS);

- the north pole science gondola (outside the envelope) includes the main GPS, and weather sensors of ambient temperature, pressure, humidity and global radiation;

- the south pole scientific payload (outside the envelope) is devoted to specific sensors. During the 2012 and 2013 campaigns, this payload was either the ozone sensor under consideration in this article or the $\mathrm{LOAC}^{4}$ sensor for measurement of aerosol properties (not in the scope of the present article, see Legain et al., 2013; Renard et al., 2016b, a).

It is seen here that the south pole ozone sensor is located close to the balloon envelope (air inlet approximately $20 \mathrm{~cm}$ below) and the question arises whether ozone deposition on the envelope could perturb measurements. To answer this question, a test was conducted in which the air inlet of a UV ozone analyser was equipped with a sampling head made of the balloon envelope material (an inextensible polymer). The sampling head consisted of a thin cone (length of about $25 \mathrm{~cm}$ and maximum diameter of $2-3 \mathrm{~cm}$ ) through which ambient air flowed before entering the teflon air inlet of the analyser. No detectable change in the analyser ozone reading was observed with or without this sampling head. No significant perturbation is thus to be expected owing to the balloon proximity.

\subsubsection{Ozone payload}

In the specific implementation of ECC ozonesonde for BLPB, the motor, the pump, the electrochemical cell and the teflon tubing of original En-Sci Z sondes were disassembled, then remounted onto an entirely new electronic card. Compared to the standard electronic implementation of ECC sondes, the major specific features are the following.

- In standard Z sondes, the electronic card and the pump motor are powered by separate batteries (at 9 and $12 \mathrm{~V}$ ). In the BLPB implementation, both motor and electronics are powered by a single lithium $3.6 \mathrm{~V}$ battery $\left(\mathrm{Li}-\mathrm{SOCl}_{2}\right)$. The motor voltage is electronically multiplied up to about $10 \mathrm{~V}$. Its rotation speed is a bit lower than under nominal voltage $(12 \mathrm{~V})$, but this affects the pump flow rate by only a few percent.

- The motor is switched on or off by electronic command following a programmable sequence described below.

\footnotetext{
${ }^{4}$ Light Optical Aerosol Counter.
}

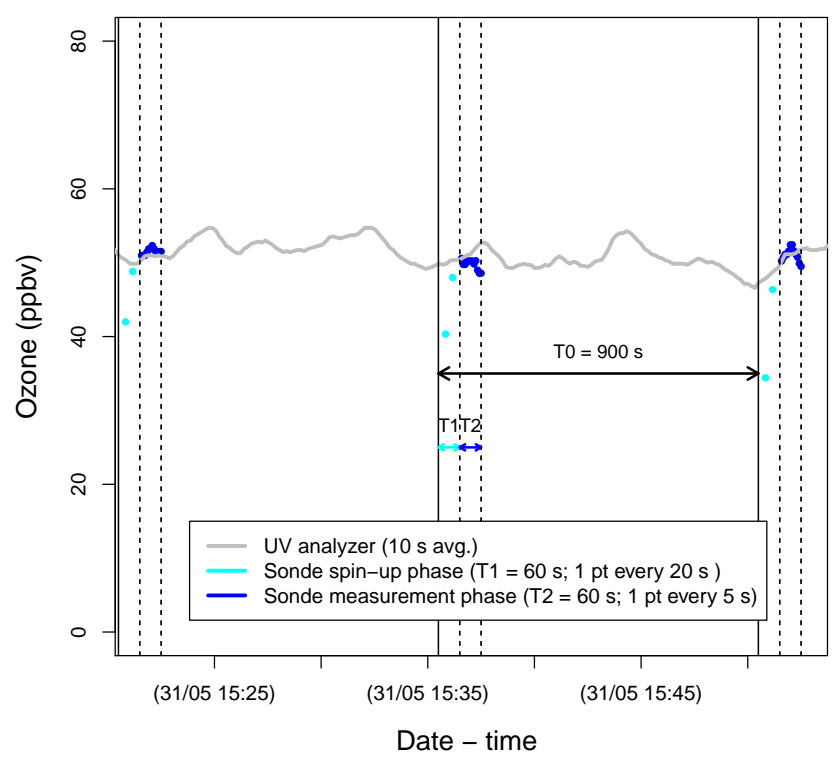

Figure 3. Example (taken from the laboratory test detailed in Sect. 3.2) showing three measurement cycles of the BLPB ozonesonde. In this illustration, the parameter values are $T_{0}=900 \mathrm{~s}$, $T_{1}=60 \mathrm{~s}$ and $T_{2}=60 \mathrm{~s}$

The measurement cycle (Fig. 3) is characterised by three different time parameters. $T_{0}$ is the overall period of the cycle, $T_{1}$ is the duration of a warm-up phase, and $T_{2}$ is the duration of the measurement phase. Two current values are recorded during the warm-up phase to check how fast the current reaches its asymptotic value (Fig. 3, cyan points). During the measurement phase, current intensities are regularly recorded (Fig. 3, blue points). The $T_{i}$ values mostly (but not always) used during the 2012 and 2013 flights were $T_{0}=900 \mathrm{~s}(15 \mathrm{~min}), T_{1}=60 \mathrm{~s}$ and $T_{2}=120 \mathrm{~s}$. This choice was inferred from laboratory tests presented in Sect. 3.

The sonde can also work in continuous mode as in a classical sounding to profile the lower atmosphere during the BLPB ascent. In this case, current intensity data are recorded every $10 \mathrm{~s}$. The continuous mode was available only during the 2013 campaigns (Sect. 4.2.1). Once the balloons had reached their ceiling altitude, cruise $T_{i}$ values were set by remote control from the operation centre.

\section{Laboratory tests}

\subsection{First tests in intermittent mode}

\subsubsection{Ozone current establishment}

A first experiment was conducted on 12 May 2011 at a fixed outdoor place to investigate the behaviour of an ECC ozonesonde (the experimental sonde, hereafter referred to as $S_{\text {Exp }}$ ) with alternating quiescence (sonde motor off) and run (sonde motor on) phases, and to evaluate its ability to repro- 

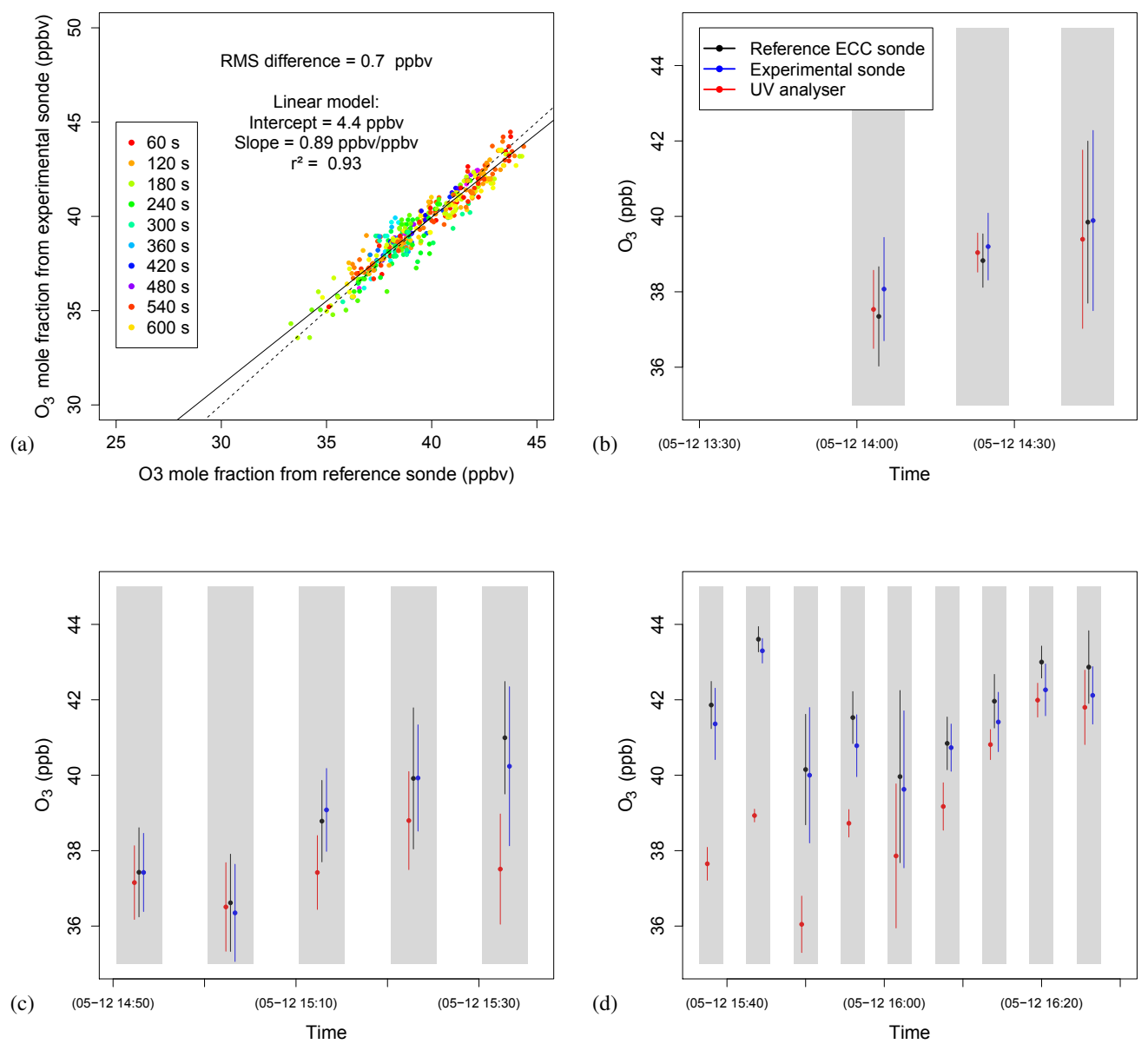

Figure 4. 12 May 2011 ground-based experiment: (a) comparison between the reference $\left(S_{\text {Ref }}\right)$ and experimental ( $\left.S_{\text {Exp }}\right)$ sondes, with the colour indicating the time since the last motor restart. Data before $60 \mathrm{~s}$ were discarded in this analysis. The solid line is the least square linear model and the dashed line the $1: 1$ fit. (b-d) Time series of ozone mole fractions provided by the UV analyser (red) and retrieved from currents in the reference (black) and the experimental (blue) ECC sondes. The background shading indicates the time intervals when the sonde motor is on. The bullets indicate the mean ozone values and the bars the standard deviations over each working period (excluding the first $60 \mathrm{~s}$ ). The durations of the quiescence and working periods were equal, but changed at different stages of the experiment: 10 min (b), $5 \min (\mathbf{c})$ and $3 \min (\mathbf{d})$.

duce correct ozone mole fractions against reference measurements. Each run-quiescence sequence was composed of two $10 \mathrm{~min}, 5 \mathrm{~min}$ and $3 \mathrm{~min}$ periods during three stages of the test.

The reference measurements were (i) a standard (En-Sci Z) ECC ozonesonde working as usual in continuous mode (the reference sonde, hereafter $S_{\text {Ref }}$ ) and (ii) a UV-absorption analyser (TEI 42i). The expected absolute accuracy is below $10 \%$ for the reference sonde in the troposphere (GAW ASOPOS panel, 2011), while it is better than 3 ppbv for the UV analyser ${ }^{5}$. The background current value of $S_{\text {Ref }}$ had to be adjusted to compensate for an obvious bias of $-5 \mathrm{ppbbv}$ with

\footnotetext{
${ }^{5}$ The latter value was obtained combining (as rooted sum of squares) the uncertainties given in Gheusi et al. (2011) for the analyser measurement itself (1.2 ppbv) and the calibration chain (2.3 ppbv).
}

respect to the other data sets (presumably caused by incorrect measurement of the background current for this sonde.)

We first compared the $S_{\text {Exp }}$ values taken at least $60 \mathrm{~s}$ after motor start to the reference sonde (Fig. 4a). A good agreement was found between both ECC sondes $\left(r^{2}=0.93\right.$; root mean square of the difference: ${\overline{\left(x_{\operatorname{Exp}}-x_{\text {Ref }}\right)^{2}}}^{1 / 2}=$ $0.7 \mathrm{ppbv})$. The comparison of both sondes with the UV analyser along the course of the test is shown in Fig. 4b-d. The ozone mole fractions are in fair agreement with each other (within 10\%), even for the shortest alternation period of 3 min. Between 15:30 and 16:00, the UV analyser was up to $5 \mathrm{ppb}$ lower than the ECC sondes (no obvious explanation for this discrepancy); nevertheless the two ECC sondes remained consistent with each other during that interval.

It was also seen in this experiment that every time the motor restarted, the ozone current rapidly grew from around 


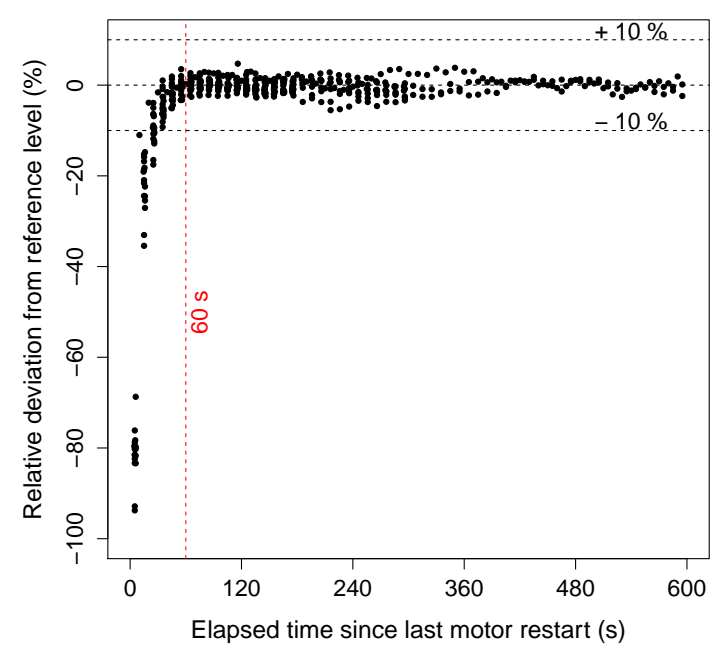

Figure 5. 12 May 2011 ground-based experiment. Deviation of $S_{\text {Exp }}$ data from the values predicted by the linear model (in relative value with respect to $S_{\text {Ref }}$ data), as a function of time elapsed since the last restart of the motor. The red dashed line marks $60 \mathrm{~s}$ (warmup time adopted thereafter). The horizontal dashed lines mark deviations of $-10 \%, 0$ and $+10 \%$.

zero to values corresponding to mole fractions comparable to those of the two other instruments. The current establishment is investigated quantitatively from the data presented in Fig. 5. The linear model presented in Fig. 4a provided a predicted $S_{\text {Exp }}$ ozone value for each $S_{\text {Ref }}$ value. Real data from $S_{\text {Exp }}$ were then compared to the prediction, as a function of time elapsed since last $S_{\text {Exp }}$ motor restart (Fig. 5b). After a rapid growth phase, a $\pm 10 \%$ agreement is achieved within a few tens of seconds. This is not surprising since ECC ozone sensors are known to have a response time to a step change in ozone of 20-30 s (GAW ASOPOS panel, 2011). In the following, we therefore adopt a warm-up time $T_{1}=60 \mathrm{~s}$ after every motor restart before considering measurements as valid.

\subsubsection{Pump flow in warm-up regime}

Pump flow rates are usually measured (during the pre-flight preparation) with the motor having been running for a few tens of minutes. In contrast, BLPB ozonesondes are designed to work for a few minutes between longer periods of quiescence. We carried out a laboratory experiment to investigate whether, after some period of quiescence, the pump flow rate of an En-Sci Z ECC sonde varies in the first minutes after restart. To this goal, we made measurements with a soapfilm flowmeter, but in a timed way with respect to the instant of motor start. As a single measurement is not instantaneous and takes about $30 \mathrm{~s}$, we consider the middle of the interval as the measurement date.

Seven measurement sequences were conducted with the same motor and pump. Between each sequence, the motor was quiescent for at least $5 \mathrm{~min}$. The obtained flow rates range between 0.206 and $0.212 \mathrm{~L} \mathrm{~min}^{-1}$ (corresponding to an overall dispersion of less than $3 \%$ ). Figure 6 shows the evolution (relative variation) of the pump flow rate during a few tens of seconds after motor start. Globally, there is a decay of the pump flow rate within the first $2 \mathrm{~min}$. The decay is in the range $0-1.7 \%$ between $60 \mathrm{~s}$ (the beginning of the measurement phase) and $120 \mathrm{~s}$.

This might induce comparable variation of the ozone current in the sonde cell for a given ozone concentration in air. If the ozone mole fraction is retrieved from ozone current measurement using a constant value for $Q_{v}$ (Eq. 1), the result might be affected in the same way (about $3 \%$ ) due to unmeasured flow rate variation during each measurement phase or between separate cycles. This is, therefore, a source of uncertainty that adds to those already reported in the literature concerning the flow rate determination. For instance, GAW ASOPOS panel (2011) reports $\pm 1 \%$ of uncertainty in the flow rate measurement by soap-film displacement technique.

For a future version of the BLPB ozonesonde, it would be interesting to develop an on-board measurement of the flow rate - providing a sufficient accuracy (less than $1 \%$ ) could be achieved with a light sensor.

In the present study, we will continue to use constant flow rate values determined as usual. However, a $3 \%$ uncertainty on ozone mole fraction attached to flow rate variation during the BLPB sonde work phase should be kept in mind.

\subsection{Long-duration test in realistic conditions}

We present here a ground-based experiment conducted from 31 May to 6 June 2012 to test the ability of the BLPB ozonesonde to monitor the evolution of ozone in the boundary layer over several days. At this stage of development, the sonde version was the same as those that flew a few weeks later over the Mediterranean during the 2012 campaign (see Sect. 4). This experiment also provided an opportunity to test the Iridium satellite connection. A TEI 49i UV-absorption ozone analyser was again deployed in the vicinity of the BLPB ozonesonde.

The values for the sonde measurement cycles were $T_{0}=$ $900 \mathrm{~s}$ (overall period), $T_{1}=60 \mathrm{~s}$ (warm-up phase) and $T_{2}=$ $60 \mathrm{~s}$ (measurement phase). During each measurement phase, 12 values of ozone current were recorded, then converted in ozone mole fractions using values measured during the sonde preparation for the background current $\left(I_{0}=0.13 \mu \mathrm{A}\right)$ and the a pump time $\left(t_{p}=32 \mathrm{~s}\right.$ per $\left.100 \mathrm{~mL}\right)$. The ambient pressure and pump temperature were measured live by the working sonde. The 12 mole fractions were finally aggregated into a single mean value (and the corresponding standard deviation) available every $15 \mathrm{~min}$.

The time series of ozone mole fraction from both instruments are shown in Fig. 7a. The BLPB ozonesonde was able to provide realistic measurements with respect to the UV analyser $( \pm 10 \%)$ along almost its entire lifetime, i.e. 

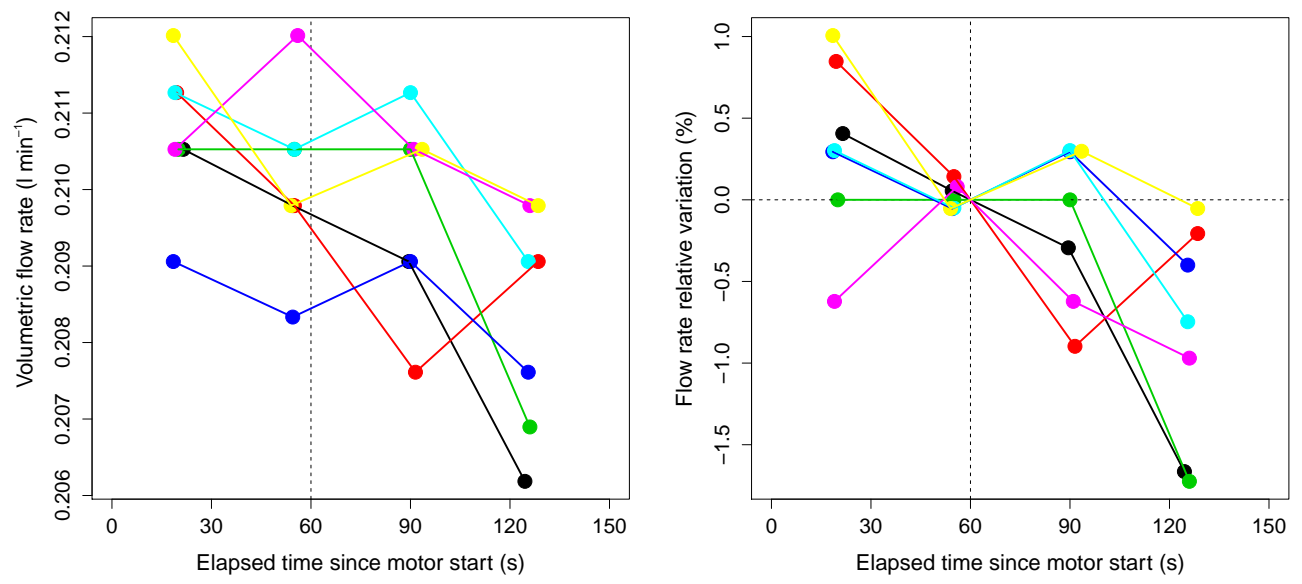

Figure 6. Pump flow rate evolution after sonde motor restart $(t=60 \mathrm{~s}$ corresponding to the beginning of the measurement phase). Each data series is differentiated with colours. (a) Volumetric flow rate $\left(\mathrm{L} \mathrm{min}^{-1}\right)$. (b) Relative deviations (in \%) from the flow rate interpolated at $t=60 \mathrm{~s}$ after restart.
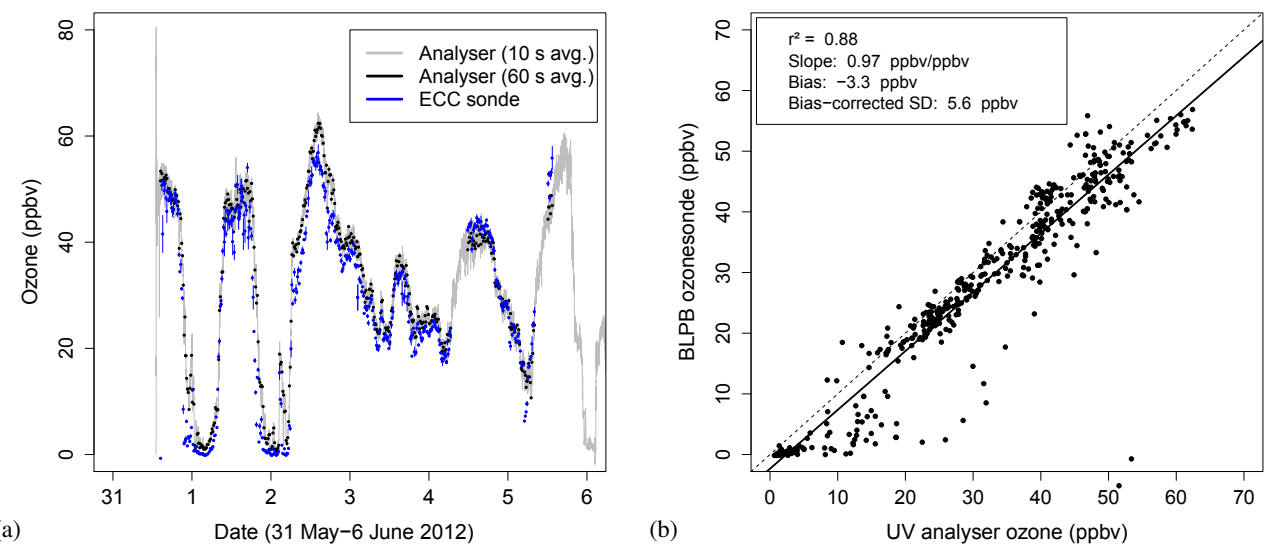

Figure 7. 31 May-6 June 2012 ground-based experiment. (a) Time series of ozone mole fraction from the UV analyser (grey curve: $10 \mathrm{~s}$ averages (analyser raw data); black dots: $60 \mathrm{~s}$ averages synchronised with the BLPB ozonesonde data) and the BLPB ozonesonde (blue dots; bars represent the standard deviation of the data recorded during each measurement phase). (b) Comparison of the ozone mole fractions from the BLPB ozonesonde against the data from the UV analyser (synchronised $60 \mathrm{~s}$ averages). The numerical results of a linear regression (solid line) are given in the figure panel. The dashed line represents the $1: 1$ correspondence.

5 days. In particular, the ozone diurnal cycles occurring during these sunny days were well captured, as well as variations on shorter timescales (e.g. on 3-4 June 2012). The linear correlation between these measurements is fair (Fig. 7b: $r^{2}=0.88$; bias: -3.3 ppbv; standard deviation of sonde minus analyser: $5.6 \mathrm{ppbv}$ ). The bias is certainly due in most part to the uncertainty on $I_{0}$.

The sonde lifetime was limited by cathode solution evaporation. In our experiment $\left(T_{0}=900 \mathrm{~s} ; T_{1}=T_{2}=60 \mathrm{~s}\right)$, the sonde worked for $3.2 \mathrm{~h}$ per day. At the evaporation rate reported by Komhyr (1969) (about $0.2 \mathrm{~mL}$ per work hour for a pump flow rate of $200 \mathrm{~mL} \mathrm{~min}^{-1}$ ), the solution would have completely evaporated in 4.7 days. This is consistent with the duration of our experiment.

It is interesting to focus on the warm-up phase of each measurement cycle, and its evolution through the sonde life- time. For each sonde measurement cycle, we compare the values measured by the sonde 20 and $40 \mathrm{~s}$ after motor start, with the mean of the 12 mole fractions recorded during the measurement phase (established current) between 60 and $120 \mathrm{~s}$ after motor start (Fig. 8a). During the first day, the ozone current reaches $60 \%$ (or $90 \%$ ) of the established value $20 \mathrm{~s}$ (or $40 \mathrm{~s}$ ) after the motor start. This is consistent with the result presented in Fig. 5b. Over several days, both percentages are seen to grow with time. By the end of the experiment, the $20 \mathrm{~s}$ values are near $90 \%$ and the $40 \mathrm{~s}$ values above $95 \%$. This means that the response time is shortening or, in other words, that the ozone sensor tends to be faster. This is due to progressive evaporation of the electrolyte in the cathode chamber. A current is induced in the electrochemical cell when some imbalance is created due to $I^{-}$oxidation by ozone, enhancing iodine concentration in the cathode so- 


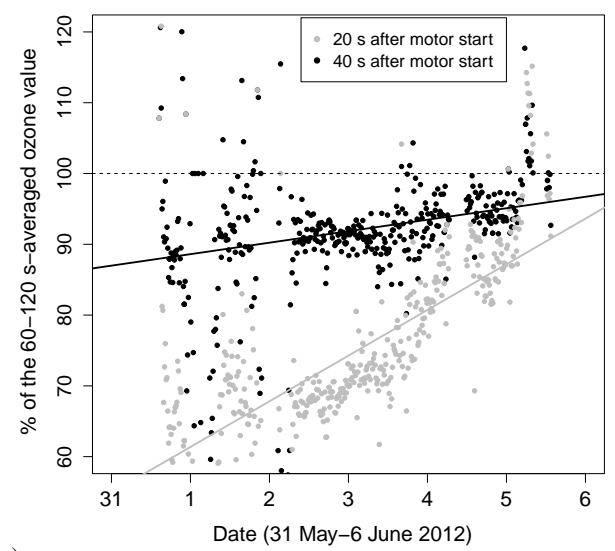

(a)

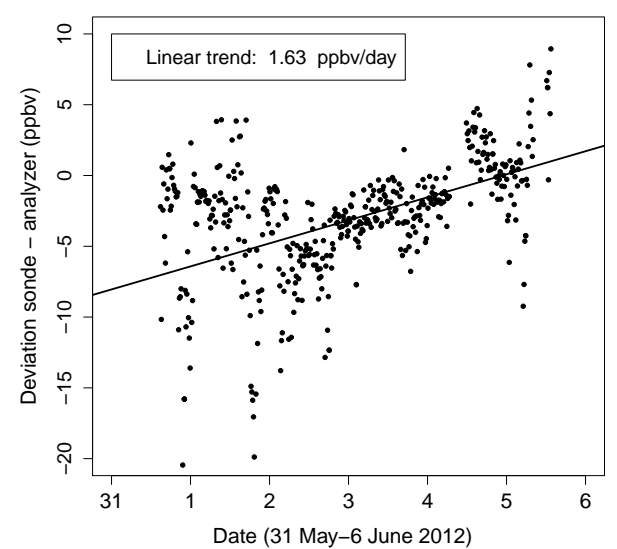

(b)

Figure 8. 31 May-6 June 2012 ground-based experiment. Evolution of the sonde behaviour over its lifetime. (a) Spin-up phase: for each measurement cycle, the represented values are percentages of the eventually established ozone value (see text for detailed definition). Grey dots represent the value measured $20 \mathrm{~s}$ after motor start; black dots represent the value measured $40 \mathrm{~s}$ after motor start. Lines represent linear regressions over each data set. (b) Deviation of the established ozone value from the UV analyser as a function of time. The line again represents a linear regression.

lution (Komhyr, 1969). It takes more time to reach a given $I_{2}$ excess concentration if the solution volume (and hence the total amount of ions to oxidise) is large. As a result, the ozonesonde response time is an indicator of the cathode solution level, and to some extent could be used as electrolyte gauge for long-duration flights.

Figure $8 \mathrm{~b}$ also shows an evolution through the sonde lifetime of the absolute deviation from the UV analyser reference. This deviation shows a positive trend at a rate of +1.63 ppbv day $^{-1}\left(\approx+0.07\right.$ ppbv h$\left.^{-1}\right)$. This drift could be linked to cathode electrolyte evaporation, which tends to increase the ion concentrations in the solution. In our experiment, in which the sonde ran until almost complete evaporation, the cathode concentrations might have doubled at half time, i.e. after about 2.5 days. From the JOSIE 2000 experiment, Smit et al. (2007) reported for ECC sondes $5 \%$ higher ozone values when using cathode solution concentrations twice those of the $0.5 \%$ half-buffer solution.

Another possible cause of measurement drift is the longterm drift of the sonde background current. Vömel and Diaz (2010) provided evidence that after a brief period of fast decay (time constant of about $20 \mathrm{~s}$ ), the background current in an ECC sonde goes on decreasing slowly as the sonde runs (slow decay with a time constant of 20-30 min). Using constant $I_{0}$ instead of actually decreasing background current should lead to underestimated ozone mole fractions, hence to a negative trend. For instance, a decrease of $I_{0}$ by $0.05 \mu \mathrm{Aday}^{-1}$ would lead to an ozone trend by -0.08 ppbv h $^{-1}$.

A greater number of similar long-duration tests against a reference measurement would be needed to characterise the drift and to demonstrate the links with either evaporation or background current drift - or a combination of both. The present experiment at least suggests that ozone trends at rates lower than a few $\pm 0.1 \mathrm{ppbvh}^{-1}$ should be considered cautiously, but trends at rates well above this value should not be measurement artefacts but real tendencies.

\section{BLPB ozonesonde flights over the Mediterranean}

\subsection{Operational overview}

Sixteen BLBP flights equipped with an ozonesonde were launched in the low troposphere over the Mediterranean Sea during three field campaigns of the coordinated project ChArMEx (http://charmex.lsce.ipsl.fr): TRAQA ${ }^{6}$ in summer 2012; ADRI-MED ${ }^{7}$ and SAFMED $^{8}$, in summer 2013. Each campaign had its own launch site (Fig. 9 and Table 1) selected for both scientific and practical reasons. All launch sites were located either on a coast or an island to avoid flight over inhabited areas just after launch. TRAQA and SAFMED (Di Biagio et al., 2015) were devoted to anthropogenic pollution transport and chemistry. The launch sites (Martigues and Levant) were located on the French Mediterranean south-east coast, which is a densely inhabited and industrialised area and, therefore, a major source of pollution in the western Mediterranean basin. The BLPB density was tuned for lowaltitude flights in the marine boundary layer or the lower free troposphere (300-900 m, Table 2). ADRIMED (Mallet et al., 2016) focused mainly on the aerosol optical properties, especially in the case of dust transport from the Saharan desert in the free troposphere. A possible influence on ozone was also investigated. The chosen launch base was on the island

\footnotetext{
${ }^{6}$ French acronym for TRAnsport and Air Quality.

${ }^{7}$ Aerosol Direct Radiative Impact in the MEDiterranean.

${ }^{8}$ Secondary Aerosol Formation in the MEDiterranean.
} 
Table 1. Launch bases during the 2012 and 2013 campaigns.

\begin{tabular}{lllr}
\hline Campaign & Period & Launch base & Geo. coord. \\
\hline TRAQA & 25 Jun - & Martigues $^{\mathrm{a}}$ & $43^{\circ} 19.96^{\prime} \mathrm{N}$ \\
& 15 Jul 2012 & & $5^{\circ} 05.22^{\prime} \mathrm{E}$ \\
ADRIMED & 10 Jun - & Minorca $^{\mathrm{b}}$ & $39^{\circ} 51.98^{\prime} \mathrm{N}$ \\
& 6 Jul 2013 & & $4^{\circ} 15.30^{\prime} \mathrm{E}$ \\
SAFMED & 22 Jul - & Levant $^{\mathrm{c}}$ & $43^{\circ} 01.31^{\prime} \mathrm{N}$ \\
& 7 Aug 2013 & & $6^{\circ} 27.61^{\prime} \mathrm{E}$ \\
\hline
\end{tabular}

${ }^{a}$ South-eastern France, Mediterranean coast. ${ }^{\text {b }}$ Sant Lluís, Minorca, Spain.

${ }^{c}$ Island off Hyères, south-eastern France, Mediterranean coast.

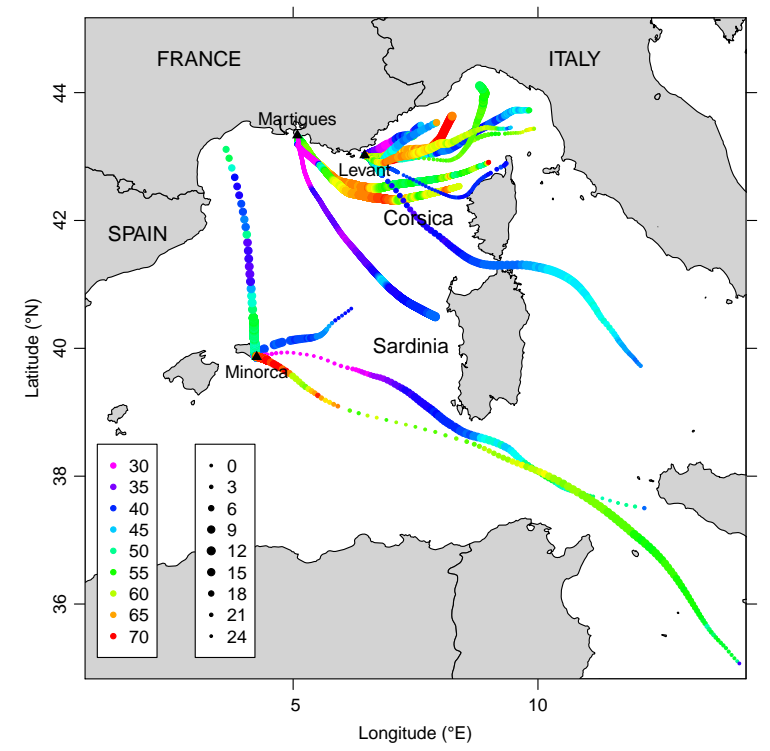

Figure 9. Trajectories of the 16 ozone BLPB flights launched in 2012 and 2013. The colour code (left box) represents the ozone mole fraction (in ppbv) measured along the trajectory. The dot size represents the solar local time (right box).

of Minorca. BLPB flights were performed at higher altitude (2000-3000 m, Table 2).

Table 2 summarises the overall performance achieved by the ozone BLPBs during the campaigns. Except in three cases (namely B53, B62 and B69), all flights were terminated when they reached the limit of the authorised flight zone (Figs. 2 and 9). B53 (from Minorca) was prematurely aborted because of remote connection failures. B62 and B69 (from Levant) were aborted owing to uncontrolled fall below a critical flight altitude $(200 \mathrm{~m}$, defined for safety reasons - risk of a sea surface touchdown which could damage the navigation gondola and render the balloon out of control). This occurred at night for both flights and might be caused by condensation on the envelope which weighted the balloon. For all flights (including B53, B62 and B69) except B61, the ozonesonde worked well until the end of the flight. In the course of flight B61, the ozone signal was suddenly lost after a turbulence ${ }^{9}$ area over the crests of Cap Corse (the elongated mountain chain forming Corsica's "index finger"), but the ozonesonde gave no sign of anomaly before that time. The other payloads on B61 went on working well for hours. The BLPB flight durations and ranges are reported in Table 2. In most cases, the BLPB ozonesondes provided data over the full flight durations, which are well beyond the lifetime of classical ozonesondes (Bénech et al., 2008, report no ozone records longer than $6 \mathrm{~h}$.). The ability to cover a full diurnal cycle was demonstrated on the occasion of several favourable trajectories (B55, B57, B62, B64 and B69).

\subsection{In-flight validations}

\subsubsection{BLPB ascent profiles compared to conventional ozone soundings}

During the 2012 and 2013 campaigns, conventional radiosoundings including ECC ozonesondes were operated in addition to BLPB launches. Some of them were launched sufficiently close in time to BLPBs (namely, B53, B54, B61 and B69) to allow for comparisons of the ascent profiles. Two other BLBPs (B64 and B65) were launched simultaneously and compared to each other. Such profile comparisons were only possible in 2013 because, before that time, the BLPB ozonesondes did not allow for continuous working mode during the launch and ascent phases.

Those radiosoundings and BLPB ascent profiles are displayed in Fig. 10. Globally, balloons launched sufficiently close in time (typically an hour or less) reveal very similar ozone profiles, whatever the type of balloon (BLPB or conventional sounding balloon) or ozonesonde (adapted or conventional ECC). This illustrates the correct behaviour of the adapted ECC sondes when used in continuous mode. It is also an indication that the proximity of the BLPB envelope from the sonde air inlet does not significantly perturb the ozone measurements even during the balloon ascent, which would be the worst configuration since the sonde is in the wake of the balloon. Note, however, that these comparisons cannot be considered validation elements for the intermittent working mode used during the BLPB cruise at ceiling levels.

\subsubsection{BLPBs at ceiling}

Once the BLPBs had reached their ceiling level, it was difficult to carry out ozone measurements specifically to validate the BLPB ozone data. We nevertheless tried to compare these data to other concurrent ozone data whenever possible.

During TRAQA, it was attempted to arrange in-flight rendezvous between the BLPB and the French research aircraft ATR42 ${ }^{10}$, which was equipped with a UV-absorption ozone analyser (among many other sensors - Di Biagio et al.,

\footnotetext{
${ }^{9}$ GPS-derived balloon vertical velocity showed quick variations with $30 \mathrm{~s}$ averaged values larger than $1 \mathrm{~m} \mathrm{~s}^{-1}$.

${ }^{10}$ SAFIRE research service: http://www.safire.fr.
} 
Table 2. Details on the 16 ozone BLPB flights launched during the 2012 and 2013 campaigns. Note that 13 other BLPBs with LOAC payload were also launched during these campaigns (Renard et al., 2016b). Those flights are not in the scope of the present article.

\begin{tabular}{|c|c|c|c|c|c|c|c|c|c|}
\hline $\begin{array}{l}\text { BLPB } \\
\text { flight \# }\end{array}$ & $\begin{array}{l}\text { Launch } \\
\text { site }\end{array}$ & $\begin{array}{r}\text { Launch } \\
\text { date and time } \\
\text { (UTC) }\end{array}$ & $\begin{array}{r}\text { Flight } \\
\text { duration } \\
(\mathrm{h})\end{array}$ & $\begin{array}{r}\text { Flight } \\
\text { range } \\
(\mathrm{km})\end{array}$ & $\begin{array}{l}\mathrm{O}_{3} \text { record } \\
\text { termination } \\
\left(\text { comment }^{\mathrm{a}}\right)\end{array}$ & $\begin{array}{l}\text { Alt. range } \\
\text { at ceiling } \\
\text { (m a.s.l.) }\end{array}$ & $\begin{array}{r}\mathrm{O}_{3} \text { range } \\
\text { at ceiling } \\
(\mathrm{ppbv})\end{array}$ & $\begin{array}{r}\text { Daytime }^{b} \\
\text { ozone trend } \\
\left(\operatorname{ppbv}^{-1}\right)\end{array}$ & $\begin{array}{l}\text { In situ } \mathrm{O}_{3} \\
\text { chemistry } \\
\left(\text { comment }^{\mathrm{c}}\right)\end{array}$ \\
\hline B06 & Martigues & $\begin{array}{r}2012 / 07 / 06 \\
04: 46\end{array}$ & 15.4 & 371 & EXIT & $470-609$ & $45-67$ & +1.6 & likely \\
\hline B08 & Martigues & $\begin{array}{r}2012 / 07 / 06 \\
02: 37\end{array}$ & 15.5 & 336 & EXIT & $417-574$ & $02-69$ & +1.8 & likely \\
\hline B10 & Martigues & $\begin{array}{r}2012 / 06 / 27 \\
01: 00 \\
\end{array}$ & 9.5 & 175 & EXIT & 566-720 & $20-46$ & +2.0 & likely \\
\hline B53 & Minorca & $\begin{array}{r}2013 / 06 / 16 \\
09: 56\end{array}$ & 14.1 & 193 & BLPB & 2996-3065 & $39-44$ & no & unlikely \\
\hline B54 & Minorca & $\begin{array}{r}2013 / 06 / 17 \\
09: 45\end{array}$ & 7.0 & 367 & EXIT & $1836-2020$ & $36-54$ & no & unlikely \\
\hline B55 & Minorca & $\begin{array}{r}2013 / 07 / 02 \\
18: 00\end{array}$ & 32.0 & 732 & EXIT & $2429-2477$ & $23-54$ & +1.2 & likely \\
\hline B57 & Minorca & $\begin{array}{r}2013 / 07 / 02 \\
13: 12\end{array}$ & 33.0 & 1014 & EXIT & $3083-3198$ & $49-75$ & -0.4 & likely \\
\hline B59 & Levant & $\begin{array}{r}2013 / 07 / 22 \\
21: 05\end{array}$ & 15.4 & 189 & EXIT & 242-395 & $45-85$ & +2.2 & likely \\
\hline B60 & Levant & $\begin{array}{r}2013 / 07 / 25 \\
06: 00\end{array}$ & 19.1 & 296 & EXIT & 526-649 & $54-66$ & +0.9 & not obvious \\
\hline B61 & Levant & $\begin{array}{r}2013 / 07 / 29 \\
21: 56\end{array}$ & $5.5^{\mathrm{d}}$ & $279^{\mathrm{d}}$ & $\mathrm{O}_{3}$ & $300-733$ & $39-42$ & (night, $\approx 0$ ) & - \\
\hline B62 & Levant & $\begin{array}{r}2013 / 07 / 30 \\
02: 59\end{array}$ & 17.4 & 626 & BLPB & $207-634$ & $36-48$ & +1.3 & likely \\
\hline B63 & Levant & $\begin{array}{r}2013 / 08 / 03 \\
06: 54\end{array}$ & 9.9 & 118 & EXIT & $467-630$ & $30-53$ & +6.5 & not obvious \\
\hline B64 & Levant & $\begin{array}{r}2013 / 08 / 03 \\
20: 57\end{array}$ & 21.6 & 304 & EXIT & 773-907 & $39-58$ & +1.3 & not obvious \\
\hline B65 & Levant & $\begin{array}{r}2013 / 08 / 03 \\
20: 57\end{array}$ & 15.3 & 299 & EXIT & 391-615 & $52-61$ & -0.7 & not obvious \\
\hline B66 & Levant & $\begin{array}{r}2013 / 08 / 04 \\
02: 52\end{array}$ & 13.3 & 176 & EXIT & 798-943 & $42-59$ & no & unlikely \\
\hline B69 & Levant & $\begin{array}{r}2013 / 07 / 25 \\
04: 00\end{array}$ & 19.4 & 265 & BLPB & $208-621$ & $41-67$ & -0.6 & not obvious \\
\hline
\end{tabular}

${ }^{a}$ EXIT is the limit of authorised flight zone reached; BLPB is the flight aborted owing to balloon failure; $\mathrm{O}_{3}$ is ozonesonde failure but the flight went on. ${ }^{\mathrm{b}}$ Maximum trend established over at least $4 \mathrm{~h}$ between sunrise and sunset. ${ }^{\mathrm{c}}$ See text for details. ${ }^{\mathrm{d}}$ These values correspond to the time of the ozone record end, but B61 went on further for about $10 \mathrm{~h}$ and $78 \mathrm{~km}$ south-eastwards.

2015). This was especially challenging owing to many constraints in the airspace over the western Mediterranean and the inability to control the balloon trajectories. Nevertheless, the aircraft managed to fly as close as possible to the balloons on rare occasions. This was the case on 6 July 2012. Two BLPBs (B08 and B06) were launched from Martigues in the early morning (at 02:37 and 04:46 UTC respectively), and followed similar trajectories toward Corsica (Fig. 11a). They eventually reached the island in the evening. B06, in particular, flew very close to the Ersa research station, where a UV-absorption ozone analyser (type Thermo 49i) was in continuous operation. The station is situated on a mountain crest at an altitude (533 ma.s.l.) close to the balloon flight level (500-550 $\mathrm{m}$ a.s.l. during the last flight hour).

The different ozone time series are shown in Fig. $11 \mathrm{~b}$ Between 03:00 and 06:00 UTC, B08 recorded questionably low ozone mole fractions (data filtered out in Fig. 11b). In the mean time, the balloon altitude dropped by about $100 \mathrm{~m}$ (Fig. 11b). It appeared from the balloon's humidity data (not shown) that B08 encountered wet conditions (relative humidity above $80 \%$ ). Possibly, water condensation on the balloon envelope and the sensors affected the balloon weight and the ozonesonde (e.g. water droplets sucked in the pump) - but we have no definitive evidence of this. After sunrise, however, B08 seemed to again provide reliable data. 


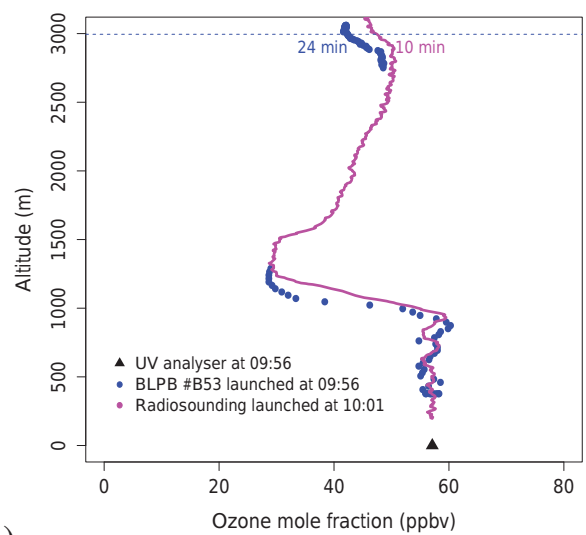

(a)

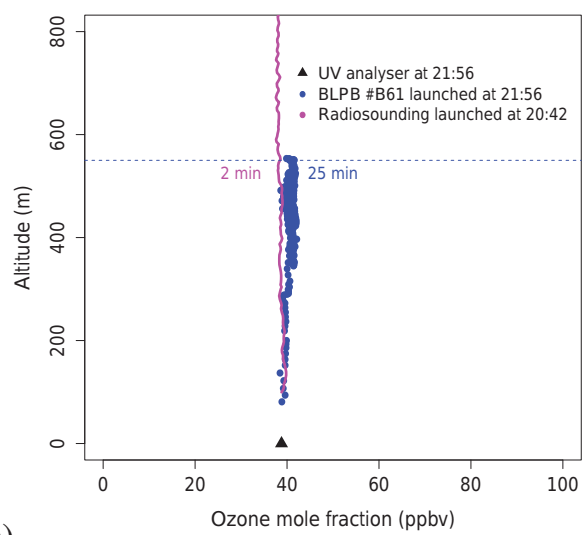

(c)

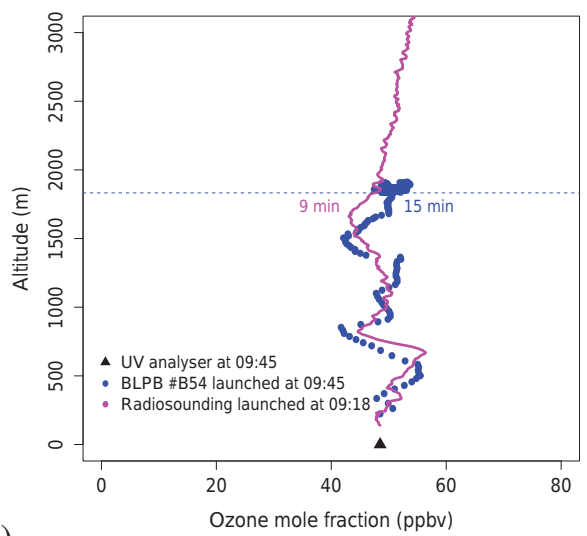

(b)

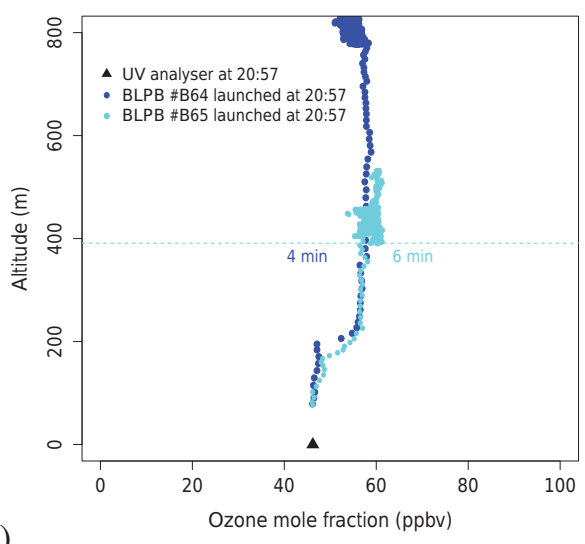

(d)

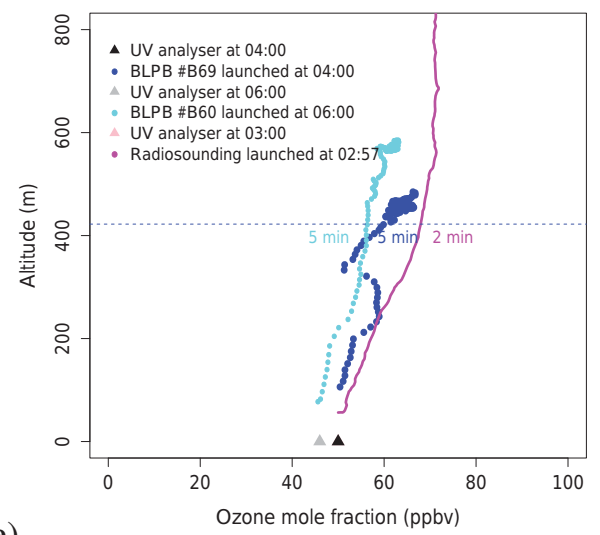

(e)

Figure 10. Ozone vertical profiles from radiosoundings and BLPBs during the 2013 campaigns. Note that the altitude range is not the same in panels (a-b) (3000 m a.s.1.) as in panels (c-e) (800 m a.s.1.). In all panels, dots represent BLPB measurements every $10 \mathrm{~s}$ (in continuous mode) while radiosounding data are represented as solid lines. The durations (in min) indicated in each panel give the time needed for each balloon to reach an estimated ceiling altitude indicated by the horizontal dashed line. Triangles represent surface ozone readings (UV analyser) at the times of BLPB launches. All useful times (UTC) are specified in figure legends.

First, it is interesting to see that B06 and B08 stayed close to each other all their way (horizontally - less than $30 \mathrm{~km}$ - as well as vertically - Fig. 11b), and that their ozone time series are in fairly good agreement. A second validation element is the consistency of the BLPB data with the aircraft measurements, especially during the rendezvous of the aircraft flight
\#27, when the aircraft flew very close to B06 (balloon in eye contact, as reported by the aircraft passengers). Lastly, ozone data from B06 and from the Ersa surface station agree fairly well by the end of B06 flight (around 20:00 UTC) when the balloon got close to the station. 


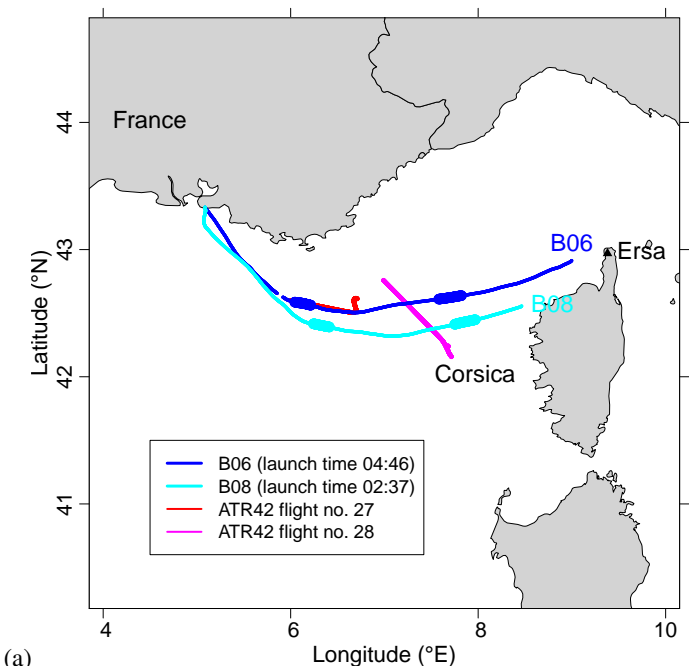

(a)

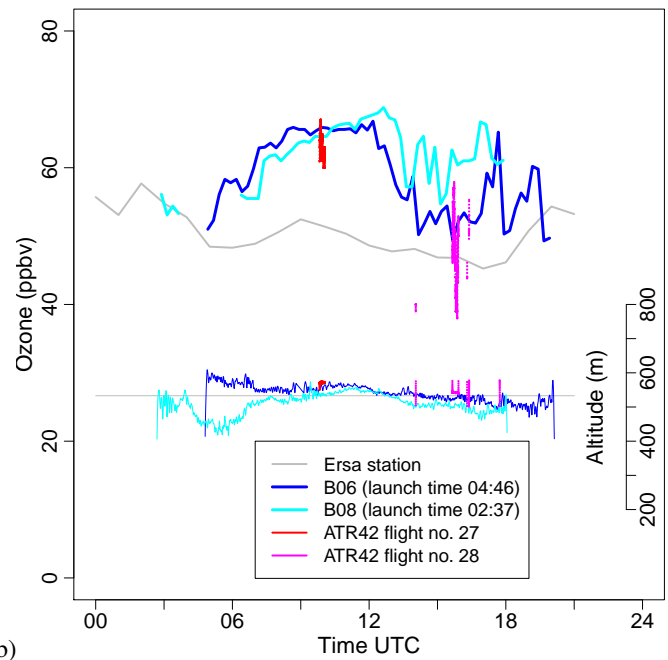

Figure 11. (a) Blue and cyan curves: trajectories of BLPBs B06 and B08 launched from Martigues on 6 July 2012 during TRAQA. Red and magenta curves: sections of the ATR42 research aircraft trajectory during two selected time intervals corresponding to rendezvous with the balloons. The balloon trajectories are broadened during these time intervals in order to indicate their location. (b) Ozone time series on 6 July 2012 from different measurements: BLPBs B06 and B08 (blue and cyan thick curves); ATR42 aircraft at the time of the rendezvous (red and magenta curves); Ersa station surface measurements at $533 \mathrm{~m}$ a.s.l. (grey curve). The station location is indicated in panel (a). The balloon, aircraft and station altitudes are also represented as thin curves (same colour code and right-hand scale).

Another interesting case for validation purpose is BLPB flight B61 on 29-30 July 2013 during SAFMED (Fig. 12). The balloon was launched from the island of Levant in the evening of 29 July. It flew toward Corsica at levels between 400 and $500 \mathrm{~m}$ a.s.l. and reached the island's west coast after about $3 \mathrm{~h}$. Then, obviously under the effect of a flow-around regime near the island, the balloon flew north-eastward along

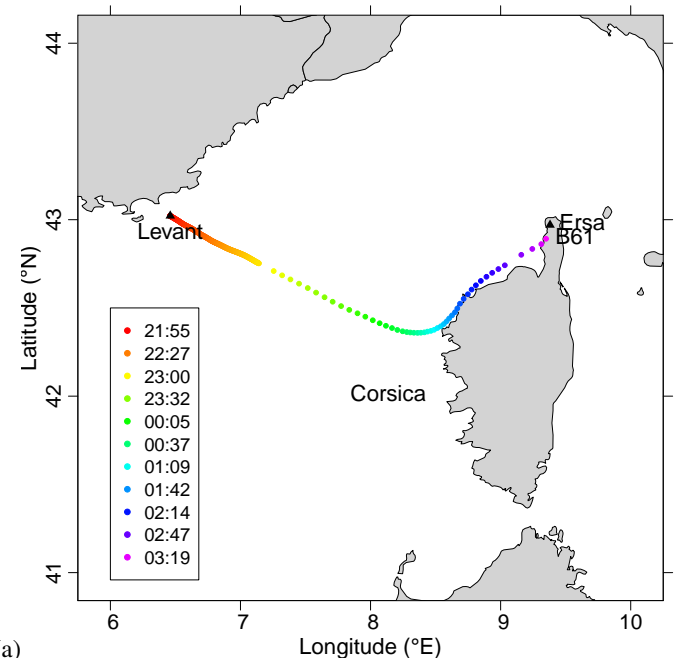

(a)

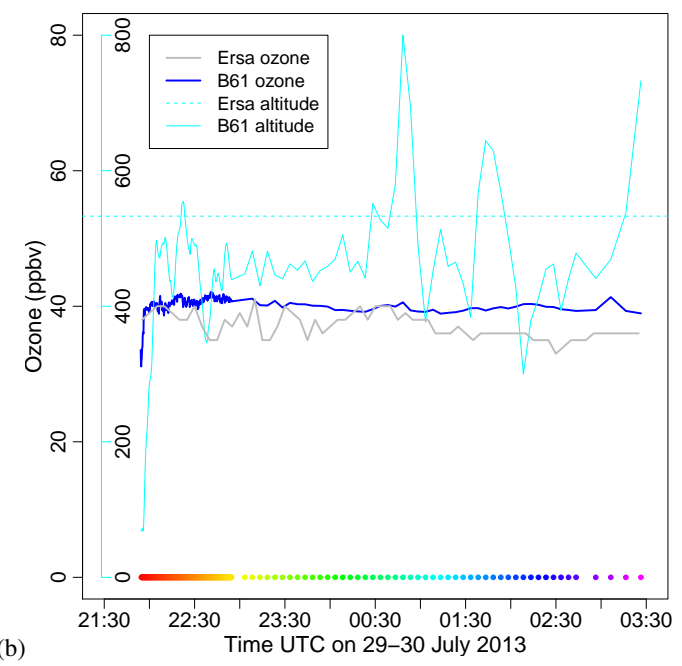

Figure 12. B61 flight on 29-30 July 2013. In both panels, the rainbow colour scale (box in panel a) represents time (UTC) at different points of the balloon trajectory. (a) B61 trajectory. (b) Ozone time series from BLPB B61 (blue curve) and Ersa surface measurements (grey curve). The cyan curve represents the balloon altitude in ma.s.l. (cyan axis). The cyan horizontal dashed line marks the altitude of the Ersa station (533 m a.s.1.). The station location is indicated in panel (a).

the coast, experiencing turbulence and strong altitude variations. B61 touched Cap Corse around 03:30 UTC. The balloon crossed the mountain chain $7 \mathrm{~km}$ south of the Ersa station. Unfortunately, B61 stopped transmitting ozone data after this time, but the balloon nevertheless went on further between Corsica and Italy for $10 \mathrm{~h}$ more (not shown in Fig. 12). The ozone surface record at Ersa (Fig. 12b) shows a homogeneous air mass all evening and night long, with mole fractions in the range 35-40 ppbv, in fair agreement with B61's ozone record.

In conclusion from these comparisons, the BLPB ozonesondes demonstrated an ability to provide ambient 
ozone mole fractions over the Mediterranean with an accuracy of about $10 \%$.

\subsection{General findings on ozone}

Ozone levels recorded over the sea during BLPB flights are globally in the range $20-80$ ppbv (Table 2 and Fig. 9). This range hides a variety of situations with different ozone backgrounds, but a general feature is that relatively weak diurnal variations were observed compared to usual groundbased observations in the summer continental boundary layer (as illustrated in Fig. 7a). During a given BLPB flight, the amplitude of ozone change generally did not exceed 20 ppbv $^{11}$. This contrasts also with the results reported by Mao et al. (2006), who investigated the pollution plume transported from New York City over the Atlantic during the 2004 ICARTT campaign, by means of ozone sensors aboard "smart balloons" (a type of constant-volume balloons used by this research group). They found high spatial and temporal ozone variability in the pollution plume at low level $(\sim 500 \mathrm{~m})$ over the ocean (e.g. variations exceeding $80 \mathrm{ppbv}$ within $10 \mathrm{~km}$ and $15 \mathrm{~min}$ ). They attributed this variability to the patchiness of the ozone field in the plume, where small pockets of high concentrations could result from a combination of factors including strong daytime ozone photoproduction and transport at small-scale.

Our BPLB ozone measurements over the Mediterranean during the three ChArMEx campaigns showed no such high variability. An explanation could be that no major ozone pollution episode occurred over the pollution source area during the ChArMEx campaigns, contrasting with the situations investigated during ICARTT. In addition, the explored environments were quite different (in terms of geographical area, local climate, sea surface temperature, weather conditions, etc.). Among those differences, highly contrasting weather conditions were encountered. While the ChArMEx flights occurred mostly in calm, fair weather conditions, the weather during ICARTT was atypically changing and complex for the summer season. For all those reasons, comparable results were not necessarily expected in terms of ozone variability.

Nevertheless, evidence of ozone photochemistry over the Mediterranean could be found during some BLPB flights. Bénech et al. (2008) investigated whether Lagrangian photochemical ozone production could be evidenced and quantified from constant-volume balloon (CVB) measurements carried out in 2000 and 2001 during the ESCOMPTE project. The authors identified CVB trajectory sections in which the considered balloon clearly drifted inside the same air mass. Ozone change in this air mass might be due to ozone chemistry, but also to vertical turbulent transport. The latter might be strong, especially near the top of the boundary layer, where large vertical gradients of ozone and other at-

\footnotetext{
${ }^{11}$ Greater amplitudes are reported in Table 2 for some flights, but the reported values include outliers.
}

mospheric species - especially water vapour - are often encountered (e.g. Brodin et al., 2011; Kalabokas et al., 2013, 2015; Di Biagio et al., 2015). An ozone trend in this case is likely to coincide with a trend in specific humidity as well. Conversely, constant specific humidity is an indication that the balloon flew in a well-mixed air mass, and ozone change in this case is more likely related to in situ chemistry.

Such an analysis has been conducted based on the ozone and specific humidity time series from the 2012-2013 BLPB flights. Ozone trends during the daytime over intervals of at least $4 \mathrm{~h}$ were observed for 12 flights out of 16 (Table 2). Ozone mole fraction increased in a majority of cases ( 9 out of 16). No obvious trend was found in four cases. Ozone decrease was observed in three cases (B57, B65, B69).

For seven flights (namely B06, B08, B10, B55, B57, B59 and B62), specific humidity (as well as potential and equivalent potential temperatures) was found to be almost constant over the considered time intervals; therefore the ozone trend can be likely attributed to ozone chemistry. Of these flights, six showed ozone build-up at rates ranging from 1.2 to $2.2 \mathrm{ppbvh}^{-1}$. Such values are lower than those reported in Bénech et al. (2008), who found a mean growth rate of $+6 \mathrm{ppbvh}^{-1}$ in the case of ozone production. During ESCOMPTE, most CVB flights took place in the continental boundary layer. This makes a major difference with oversea flights, since the continental boundary layer is constantly supplied with ozone precursors (nitrogen oxides and volatile organic compounds) from the surface. The Marseilles area is especially favourable to ozone production. The CVBs during ESCOMPTE were launched from industrial or urban sites, and it is likely that the air masses were initially rich in nitrogen oxides. Then the balloons were transported over the rural hinterland, where emissions of biogenic volatile organic compounds from the Mediterranean vegetation are strong in summer (Simon et al., 2006). This forms the cocktail for explosive ozone production in the boundary layer, as observed by Cros et al. (2004). The 2012 TRAQA and 2013 SAFMED BLPBs were launched from the same area as during ESCOMPTE, but wind conditions were chosen for flights over sea. In such conditions, the initial precursor concentrations in the air mass are potentially similar but no further supply of precursors is expected from the sea surface. This may be an explanation for slower ozone growth in the air mass. Another point is that no major pollution episode was encountered in the area during TRAQA and SAFMED, unlike what was observed during ESCOMPTE, and this might bias the comparison $^{12}$. B63 is the only flight that exhibits rapid ozone increase $\left(+6.5 \mathrm{ppbv} \mathrm{h}^{-1}\right)$ between 12 and $16 \mathrm{~h} \mathrm{UTC}$, but this is associated to large specific humidity variations as well as

\footnotetext{
${ }^{12}$ Considering the likely cases of ozone photoproduction (Table 2, flights B06, B08, B10, B55, B59 and B62), the mean ozone mixing ratio recorded during these flights is $45 \mathrm{ppbv}$. A similar estimation from Bénech et al. (2008, their Table 3, cases 1, 3, 7, 10-12, $15,18-20,22,26-28)$ yields 60 ppbv.
} 
a balloon descent of about $100 \mathrm{~m}$. Hence, it is not obvious to conclude in situ ozone production. At least part of this growth might be attributed to turbulent transport or to the fact that the balloon sampled different layers in the meantime (the balloon not being Lagrangian along the vertical).

A remarkable case of in situ ozone production was found during flight B55 from Minorca. Even though the ozone growth is relatively slow $\left(+1.2 \mathrm{ppbv} \mathrm{h}^{-1}\right)$, it occurs at high altitude (2400-2500 m) in the free troposphere. Prior to our study, Morris et al. (2010) reported ozone production in a free tropospheric air mass downwind of a tropical convective cell, also measured by an ozonesonde. In this case, however, the air mass tracking was not intentional and resulted by chance from vertical oscillations of a conventional sounding balloon in up- and downdraughts. Flight B55, in contrast, was intentionally designed to follow a Lagrangian trajectory in the free troposphere. The flight is presented in more detail in Sect. 4.4.2.

B57 is the only case of ozone decrease likely related to in situ destruction (in the free troposphere, again). The other two cases of decrease (B65, B69, both at low altitude) are more ambiguous, owing to a larger variability in specific humidity.

\subsection{Remarkable flights}

\subsubsection{Low-altitude flight B62}

B62 (Fig. 13) is an especially interesting flight, which covered almost a full diurnal cycle. Its remarkable trajectory passed between the Corsica and Sardinia islands, and the flight revealed interesting features of the Mediterranean lower troposphere. The specific humidity time series allows us to clearly distinguish four flight sections during which it remained roughly constant (Fig. 13b). It can be assumed that the balloon sampled the same air mass inside each flight section; therefore the time evolution of the measured variables can be considered quasi-Lagrangian.

Flight section 1 occurred in the late night and early morning (B62 launched at 02:59 UTC) and ended around 06:30 UTC. Once the balloon had reached its ceiling altitude, it oscillated between 400 and $500 \mathrm{~m}$ a.s.l. The specific humidity also fluctuated between 6 and $8 \mathrm{~g} \mathrm{~kg}^{-1}$, and, to some extent, mirrored the ozone variations. It may be concluded that the balloon flew in a turbulent air mass where vertical gradients of both humidity and ozone existed - probably near the top of the marine boundary layer. As specific humidity is most likely to decrease with height, and humidity and ozone variations are opposite in this case, higher ozone concentrations seem to be present aloft. Ozone shows no overall trend over flight section 1, and no chemical evolution is to be expected.

Flight section 2 occurred between 06:30 and 10:40 UTC. This new air mass was significantly more moist (11$12 \mathrm{~g} \mathrm{~kg}^{-1}$ ) than the previous one. The flight altitude again
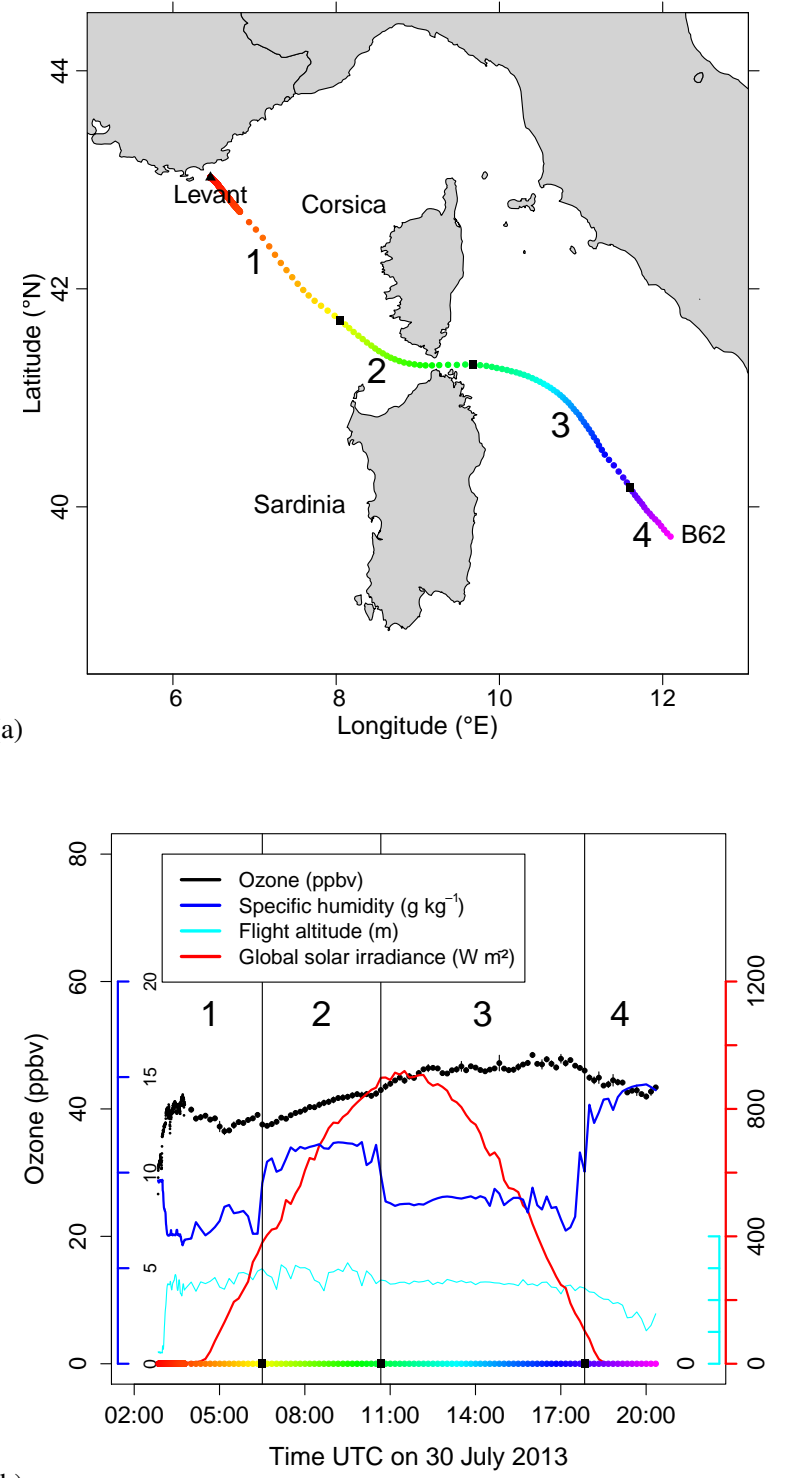

(b)

Figure 13. B62 flight launched on 30 July 2013 at 02:59 UTC. In both panels, the rainbow colour scale represents time (UTC) at different points of the balloon trajectory. Black square marks delimit 4 flight sections numbered 1 to 4 (see text). (a) B62 trajectory. (b) Time series from B62 measurements: ozone mole fraction (black dots; bars represent one standard deviation around the mean value during the measurement phase - see Sect. 2.2.2); air specific humidity (blue line and related scale in $\mathrm{g} \mathrm{kg}^{-1}$ ); balloon flight altitude (cyan line and related scale in ma.s.l.); incoming shortwave irradiance (red line and related scale in $\mathrm{W} \mathrm{m}^{-2}$ ).

showed fluctuations but specific humidity remained almost constant, indicating a turbulent well-mixed layer - the marine boundary layer. In the meantime, ozone concentration showed a linear increase of $+1.4 \mathrm{ppbvh}^{-1}$. This is a clear indication of ozone photochemical production in the marine boundary layer. 
By the end of flight section 2, B62 accelerated (from 8 up to $15 \mathrm{~m} \mathrm{~s}^{-1}$ - not shown) while passing between the two islands. This is the evidence of a gap flow acceleration (Venturi effect). In addition, the flow tended to further accelerate after the point of maximum constriction between the islands - the signature of a supercritical hydraulic flow. This might occur in particular when the lower troposphere acts as a stable twolayer flow, the lower one being the marine boundary layer and the upper one the stable free troposphere, separated by a temperature inversion (e.g. Lesouef et al., 2013, and references therein). A noticeable point is that the interface lowers as the lower layer accelerates (owing to conversion of potential into kinetic energy). This can explain the sudden change of air mass at 10:40 UTC shortly after the gap: the quasihorizontal isopycnic balloon trajectory probably crossed the lowering interface. The sudden decrease of specific humidity (down to $8 \mathrm{~g} \mathrm{~kg}^{-1}$, Fig. 13b), balloon deceleration (Fig. 13a) and temperature jump by about $+4{ }^{\circ} \mathrm{C}$ (not shown) support the assumption that the balloon exited the boundary layer and entered the free troposphere. The temperature jump also supports the existence of a temperature inversion between the layers.

Flight section 3 occurred between 10:40 and 17:50 UTC. During this time the balloon sampled the lower free troposphere, although it flew in the same altitude range as in the previous flight sections. This implies that the marine boundary layer was not as deep as on the other side of Corsica and Sardinia. Ozone increased globally by $0.7 \mathrm{ppbv} \mathrm{h}^{-1}$, at a higher rate during the first $2-3 \mathrm{~h}$ and more slowly after that. Here again, this positive trend can be attributed to photochemical ozone production.

During the last flight, flight section 4 in the evening (17:50-20:20 UTC), B62 experienced very moist conditions (specific humidity around $14 \mathrm{~g} \mathrm{~kg}^{-1}$, relative humidity above $80 \%$ ), again within the marine boundary layer. The balloon progressively lost its altitude. Ozone decrease was observed while specific humidity was relatively constant. However, the balloon descent is significant and the ozone trend might be linked to either a vertical gradient or ozone chemical destruction. Finally, the balloon went below the critical altitude of $200 \mathrm{~m}$ and the flight was aborted.

A numerical simulation covering the B62 flight period was performed by means of the chemistry-transport model MOCA-GE ${ }^{13}$ developed by Météo-France (Peuch et al., 1999). The model covers the planetary boundary layer, the free troposphere, and the stratosphere. It provides a number of optional configurations with varying domain geometries and resolutions, as well as chemical and physical parameterisation packages (see El Amraoui et al., 2010, 2014). It offers the flexibility to use several chemical schemes for stratospheric and tropospheric studies. The model uses a semiLagrangian transport scheme and includes 47 hybrid vertical

\footnotetext{
${ }^{13}$ MOdèle de Chimie Atmosphérique à Grande Echelle (LargeScale Chemistry Atmospheric MOdel).
}
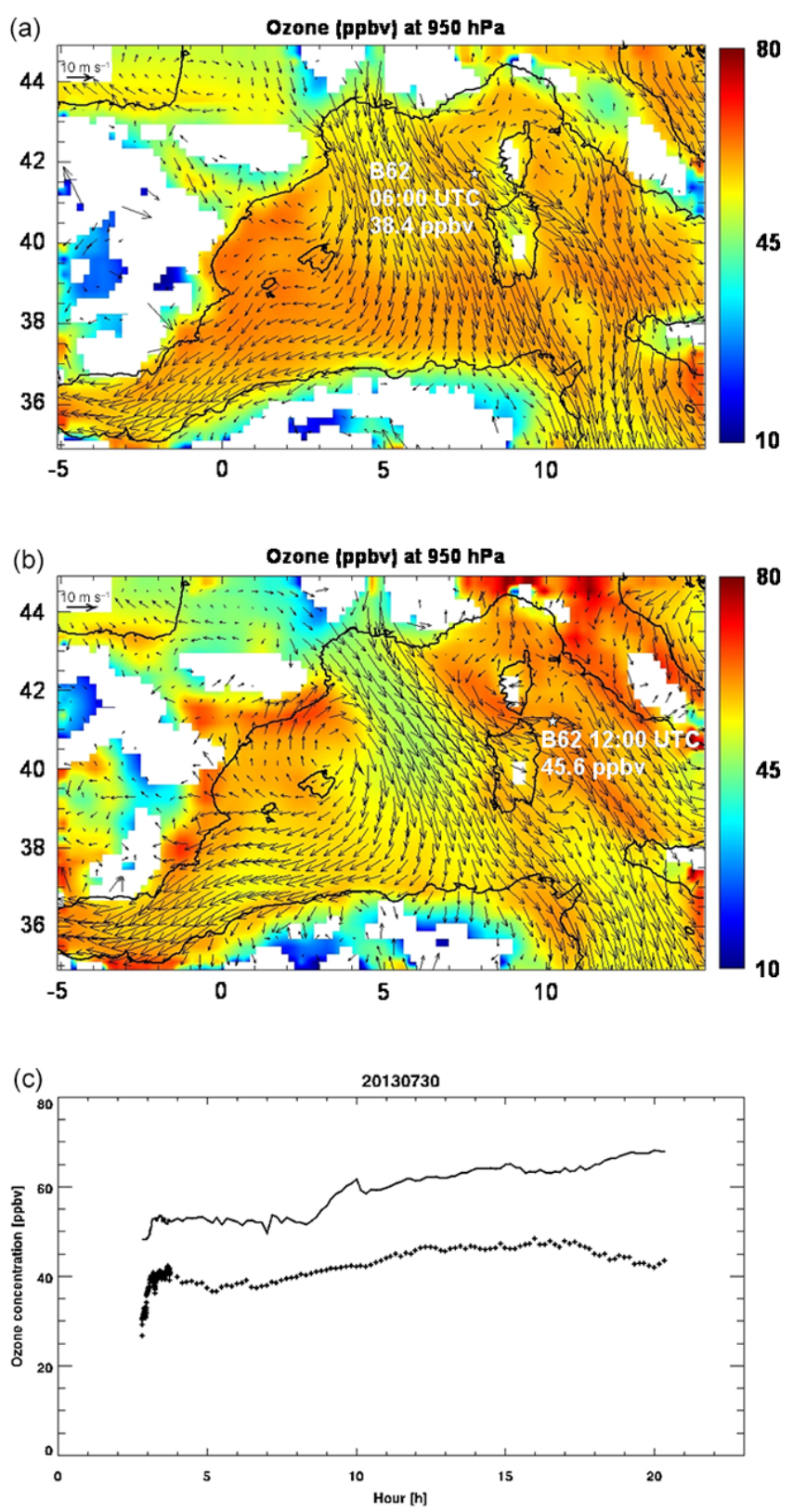

Figure 14. (a) Ozone mole fraction (colour code in ppbv) and wind field (vectors) at $950 \mathrm{hPa}$ pressure level given by the chemistrytransport model MOCAGE, at 06:00 UTC on 30 July 2013. (b) As in (a), but at 12:00 UTC. In panels (a) and (b), balloon B62 positions at the respective times are marked by stars. (c) Observed (cross marks) and simulated (solid line) ozone mole fraction time series (in ppbv) along the B62 trajectory (abscissa: time in UTC on 30 July 2015).

levels from the surface up to $5 \mathrm{hPa}$, giving the model a vertical resolution between 40 and $400 \mathrm{~m}$ in the boundary layer and between 400 and $800 \mathrm{~m}$ in the upper layers. In this study, MOCAGE is forced dynamically by wind and temperature fields from the ARPEGE model analyses (Courtier et al., 1991). It is run over a regional nested domain (Mediterranean 
area, see Fig. 15) at a horizontal resolution of $0.2^{\circ} \times 0.2^{\circ}$ forced by the $2^{\circ} \times 2^{\circ}$ global domain.

For the global domain, we used the GEIA (Guenther et al., 1995) and the IPCC (Dentener et al., 2005) inventories for natural and anthropogenic emissions respectively. For the regional domain, we used the MACC II inventory (Kuenen et al., 2011) for the anthropogenic emissions, the GFAS 1.1 product (Kaiser et al., 2012) for biomass burning emissions and the GEIA inventory for the natural emissions.

Figure $14 \mathrm{a}$ and $\mathrm{b}$ show the ozone and wind vector fields from MOCAGE approximately at the balloon altitude $(950 \mathrm{hPa})$ at 06:00 and 12:00 UTC respectively. The balloon was transported offshore from the continent along the northeastern edge of a low-level wind jet locally called mistral. This wind jet is caused by the Venturi effect between two mountain areas in France (Alps and Massif Central), then further accelerates over the sea due to the supercritical nature of the flow (Drobinski et al., 2001). On this day, a branch of the mistral jet was channelled between Corsica and Sardinia, and the balloon was obviously driven in this branch. The model wind field is consistent with the real balloon trajectory (Fig. 13a). In the model, ozone increase can be seen in this air mass, caused by in situ photochemical production. The direct comparison of the observed and simulated ozone time series along the (real) balloon trajectory reveals a parallel evolution over the course of the day, with a daytime increase of about $10 \mathrm{ppbv}$. However, the model overestimates ozone mole fractions by about $15 \mathrm{ppbv}$ compared to the observations (Fig. 14c).

\subsubsection{Free troposphere flight B55}

B55 flight was launched on 2 July 2013 at 18:00 UTC from Minorca. The balloon flew east-south-eastward for $32 \mathrm{~h}$ in the free troposphere at altitudes ranging from 2350 to $2480 \mathrm{~m}$ a.s.l. (Fig. 15). It exited the authorised flight zone while approaching Sicily.

In order to characterise the origin of the air mass sampled by the balloon, an ensemble of 27 ten-day backward trajectories was computed with the online HYSPLIT model (Draxler and Rolph, 2014; Stein et al., 2015). The trajectory endpoints all correspond to the balloon current position at 21:00 UTC on 2 July $2013^{14}$. The trajectory ensemble is shown in Fig. 15a. Before passing over Minorca, the trajectories had followed one of two main paths.

- Some trajectories experienced a slow anticyclonic motion over northern Africa, and before this in the western Mediterranean boundary layer. In this case, the model

\footnotetext{
${ }^{14}$ Control parameters used for the HYSPLIT simulation: trajectory endpoint at $39.912260^{\circ} \mathrm{N}, 4.563480^{\circ} \mathrm{E}, 2400 \mathrm{~m}$ a.s.l. on 2 July 2013, 21:00 UTC; ensemble option activated; global REANALYSIS archive used for meteorological fields (details available on https://www.ready.noaa.gov/gbl_reanalysis.php); model vertical velocity used for vertical motion calculation.
}

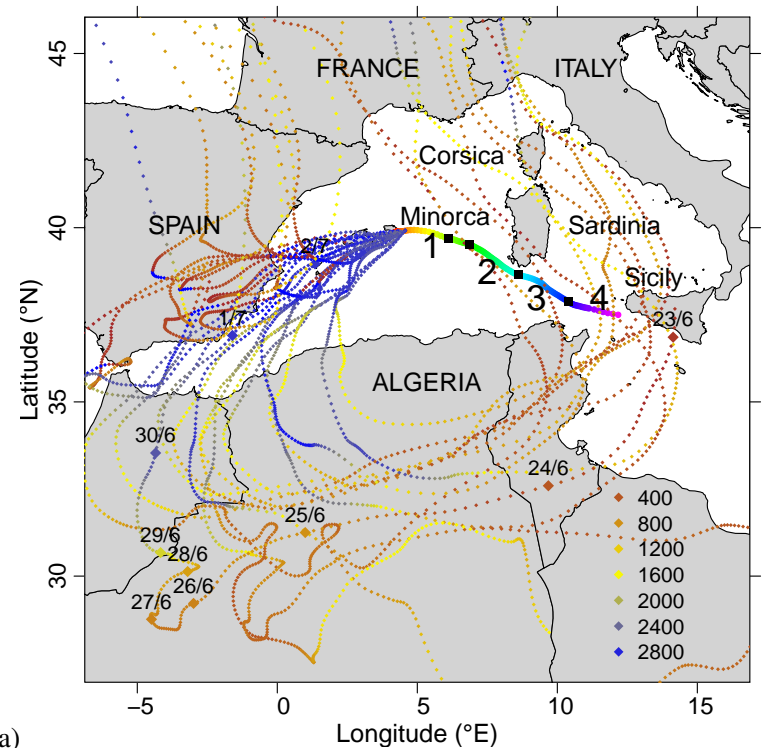

(a)

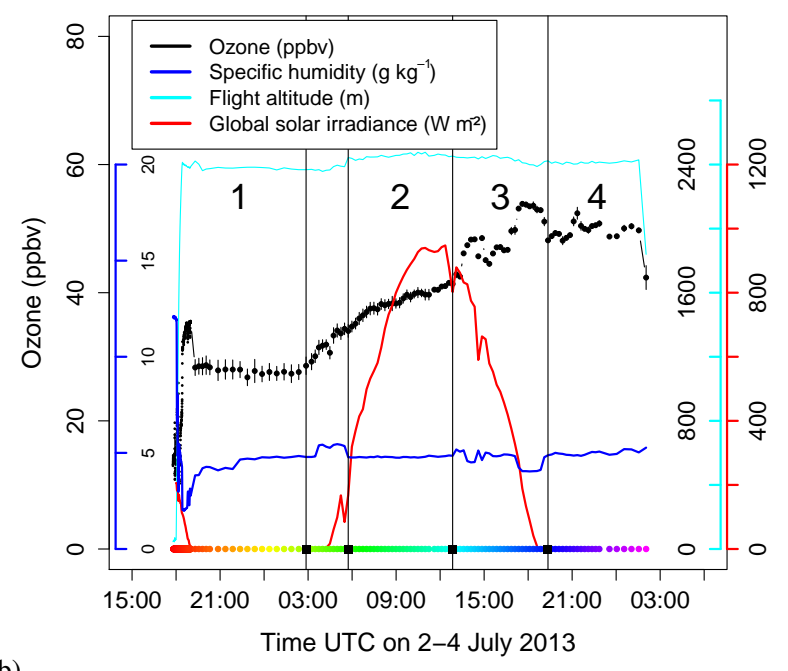

(b)

Figure 15. B55 flight launched on 2 July 2013 at 18:00 UTC. Same legend as in Fig. 13 concerning the balloon. Panel (a) shows in addition an ensemble of 10-day HYSPLIT backward trajectories (diamonds) ending on 2 July 2013 21:00 UTC at the current balloon position (trajectory step $1 \mathrm{~h}$; for one illustrative trajectory, larger diamonds mark the parcel position daily at 00:00 UTC; the parcel altitudes are represented as a brown-to-blue colour scale, in $\mathrm{m}$ a.s.l.).

suggests no major recent anthropogenic influence, but aged and diluted residual pollution from the Mediterranean boundary layer might be present.

- Other trajectories were more recently in the boundary layer over south-eastern Spain. In this case, fresh and more concentrated pollution can be expected.

The day of 3 July 2013 was completely covered by the balloon measurements. A remarkable ozone increase of more 
than $25 \mathrm{ppbv}$ was observed during the daytime along the flight track, while specific humidity remained relatively constant around $4-5 \mathrm{~g} \mathrm{~kg}^{-1}$. Again, we defined four flight sections for convenience (Fig. 15). Section 1 was mostly during the night, with a near-constant ozone mole fraction around 27-28 ppbv. Ozone started then to increase in the early morning at around 03:00 UTC. During a $3 \mathrm{~h}$ transition period, both the balloon altitude and the specific humidity varied. Therefore, the cause of the ozone mole fraction increase is not clear for that period.

During flight section 2, the specific humidity was remarkably constant $\left(4.7-4.9 \mathrm{~g} \mathrm{~kg}^{-1}\right)$ while the ozone mole fraction was growing at a rate of $1.0 \mathrm{ppbvh}^{-1}$. The most likely explanation for this ozone increase is in situ photochemistry. During section 3, ozone variations around the overall trend mirror humidity variations but still the ozone baseline keeps on growing at about the same average rate $\left(1.0 \mathrm{ppbvh}^{-1}\right)$. During the final night-time section 4 , ozone shows no obvious trend after 21:00 UTC.

To our knowledge, such a continuous Lagrangian observation of ozone photochemical production in the free troposphere has not been reported previously. This case study deserves further work, especially with numerical modelling, to give more support to this hypothesis and specify the chemical mechanism in play.

\section{Summary and future work}

A specific adaptation of electrochemical concentration cell (ECC) ozonesonde has been developed for long-duration isopycnic flights in the lower atmosphere aboard the last generation of boundary-layer pressurised balloons (BLPBs): small constant-volume balloons developed by CNES. The main challenge was the relatively short lifetime of conventional ECC ozonesondes. Whereas BLPBs can fly and transmit data for days or even weeks, the working time of ECC ozonesondes is limited to a few hours, chiefly owing to electrolyte evaporation in the cathode chamber. The adopted strategy was to save electrolytes by alternating short working phases (pump motor on) and longer quiescence periods (pump motor off).

The adaptation consists of an entirely new electronic implementation of existing elements from commercial ECC EnSci Z sondes, namely motor, pump and electrochemical cell. The major specific feature of the new electronic card is that the pump motor can be switched on or off following a programmable sequence composed of three steps: (i) a warm-up period (motor on), (ii) a measurement period (motor still on) and (iii) a quiescence period (motor off). Laboratory tests presented in this article show that a 1 min warm-up period is sufficient to reach a stabilised ozone measurement that is consistent with the typical response time of ECC sondes to an ozone step, which is a few tens of seconds. The durations of the measurement period (typically $1-2 \mathrm{~min}$ ) and of the qui- escence period (such that the overall 3-step sequence is typically 15 to $30 \mathrm{~min}$ ) can be adjusted to consume the electrolyte more or less rapidly, depending on the expected flight duration and desired sampling rate.

Among other laboratory tests, an outdoor ground-based experiment was conducted over several days in order to evaluate the new ozonesonde performance against the data from a UV absorption analyser, which was considered to be a reference. With warm-up and measurement periods of 1 min each and an overall sequence of $15 \mathrm{~min}$, the ozonesonde provided data within $\pm 10 \%$ from the reference for more than 4 days, capturing several pronounced ozone diurnal cycles (in the range $\sim 0-60 \mathrm{ppbv}$ ) as well as features at shorter timescale. The obtained agreement is within the expected absolute accuracy of ECC ozonesonde data in the troposphere $(10 \%$, according to the GAW ASOPOS panel, 2011).

The new ozonesonde was then carried out over the western Mediterranean aboard 16 BLPB flights during three campaigns in summer 2012 and 2013. Two launch bases were located on the French Mediterranean coast, in the Marseilles and Toulon areas, and a third one was on Minorca. Drifting altitudes were in the range $0.25-3.2 \mathrm{~km}$. The longest flight lasted more than $32 \mathrm{~h}$ and covered more than $1000 \mathrm{~km}$ from Minorca to the south of Malta.

The concurrent data sets available from the campaigns (aircraft or ground-based UV analyser measurements) suitable for in-flight validation all show reasonable agreement with the BLPB ozone data.

Prior to our study, Bénech et al. (2008) considered ozonesonde measurements from low-altitude isopycnic balloons launched in 2000 and 2001 from the Marseilles area (at that time, standard ECC ozonesonde were used, over much shorter flight durations). Following the method used by these authors, we also identified flight segments for which specific humidity remained nearly constant - an indication that the balloon flew for some time within the same homogeneous air mass and, therefore, that the ozone measurement can be considered quasi-Lagrangian with good confidence. In such cases, the observed ozone trend can be attributed with good confidence to ozone chemistry. In a majority of cases, the ozone mole fraction was found to increase during the daytime, with growth rates in the range $1-2 \mathrm{ppbvh}^{-1}$. This is significatively less than the mean growth rate found by Bénech et al. (2008) $\left(6 \mathrm{ppbvh}^{-1}\right)$, but in our case, all flights were over sea, whereas their results were obtained mainly over land. Moreover, several major pollution episodes were experienced during the 2000-2001 campaigns, but this was not the case in 2012-2013.

Beyond the overview presented in this article, several interesting flights were investigated in more detail, with more attention paid to other experimental data from the 2012-2013 campaigns as well as chemistry-transport numerical simulations. Of these flights, one (B55) flew in the free troposphere (around $3000 \mathrm{~m}$ a.s.1.) and revealed ozone growth by about $1 \mathrm{ppbvh}^{-1}$ during the daytime, while specific humidity re- 
mained nearly constant. This is potentially the first in situ observation of ozone photoproduction in the free troposphere along a continuous Lagrangian trajectory. However, further work is needed to confirm this result and study the cause of the observed evolution.

From a technical point of view, an interesting evolution of the BLPB ozonesonde (and potentially also of conventional ECC sondes) would be the on-board measurement of the pump flow rate. Indeed, the ozone current measured in the ECC is proportional to the pump flow rate. From our laboratory tests, it was found to vary by $1-2 \%$ during the first 3 min after the pump motor has been turned on. This could help to reduce the uncertainty associated with the ozone measurement. However, the major uncertainty source for tropospheric ozone measurements is related to the sonde background current (i.e. the current measured in absence of ozone). This is a general concern for all types of ECC ozonesondes and reducing this source of uncertainty remains an open research challenge (Vömel and Diaz, 2010; GAW ASOPOS panel, 2011).

\section{Data availability}

The data sets used in this study are all available on http://mistrals.sedoo.fr/ChArMEx/ under the following DOIs:

Laboratory tests

- doi:10.6096/MISTRALS-ChArMEx.1456 (Gheusi, $2016 \mathrm{~g}$ )

- doi:10.6096/MISTRALS-ChArMEx.1458 (Gheusi, 2016h)

- doi:10.6096/MISTRALS-ChArMEx.1459 2016i)

Field campaign 2012

- doi:10.6096/MISTRALS-ChArMEx.998 (Piguet and Perrin, 2013)

- doi:10.6096/MISTRALS-ChArMEx.765 (Gheusi, $2012 b)$

- doi:10.6096/MISTRALS-ChArMEx.764 (Gheusi, 2012a)

Field campaign 2013

- doi:10.6096/MISTRALS-ChArMEx.1450 2016a)

- doi:10.6096/MISTRALS-ChArMEx.1451 2016b)

- doi:10.6096/MISTRALS-ChArMEx.1452 2016c)

\author{
- doi:10.6096/MISTRALS-ChArMEx.1453 (Gheusi, \\ 2016d) \\ - doi:10.6096/MISTRALS-ChArMEx.1454 (Gheusi, \\ 2016e) \\ - doi:10.6096/MISTRALS-ChArMEx.1455 (Gheusi, \\ 2016f)
}

Acknowledgements. The ozone BLPB project was supported and funded by the French space agency CNES, and also by the French national research institute CNRS/INSU through its research programme MISTRALS/ChArMEx. The TRAQA campaign was partly supported by ADEME (French environment and energy management agency). We gratefully thank all members of the CNES technical staff, who brought priceless support during and around the field campaigns, as well as the SEDOO group of the Observatoire Midi-Pyrénées who made the forecast trajectories used to plan the BLPB launches available. The authors also acknowledge the NOAA Air Resources Laboratory (ARL) for the provision of the HYSPLIT transport and dispersion model and READY website (http://www.ready.noaa.gov) used in this publication.

Edited by: J. Joiner

Reviewed by: two anonymous referees

\section{References}

Bénech, B., Druilhet, A., Cordesse, R., Dartigues-Longues, B., Fournet-Fayard, J., Mesnager, J.-C., Durand, P., and Malaterre, A.: Un dispositif expérimental utilisant des ballons plafonnants pour l'étude de la couche limite atmosphérique, Adv. Space Res., 7, 77-83, 1987a.

(Gheusi, Bénech, B., Durand, P., and Druilhet, A.: A case-study of a nonhomogeneous boundary layer (AUTAN 84 experiment), Annal Geophys. B, 5, 451-460, 1987b.

Bénech, B., Ezcurra, A., Lothon, M., Said, F., Campistron, B., Lohou, F., and Durand, P.: Constant volume balloons measurements in the urban Marseille and Fos-Berre industrial ozone plumes during ESCOMPTE experiment, Atmos. Environ., 42, 55895601, doi:10.1016/j.atmosenv.2008.03.011, 2008.

Brodin, M., Helmig, D., Johnson, B., and Oltmans, S.: Comparison of ozone concentrations on a surface elevation gradient with balloon-borne ozonesonde measurements, Atmos. Environ., 45, 5431-5439, doi:10.1016/j.atmosenv.2011.07.002, 2011.

Businger, S., Chiswell, S., Ulmer, W., and Johnson, R.: Balloons as a Lagrangian measurement platform for atmospheric research, J. Geophys. Res., 101, 4363-4376, 1996.

Businger, S., Johnson, R., and Talbot, R.: Scientific insights, B. Am. Meteorol. Soc., 87, 1539-1554, doi:10.1175/BAMS-87-111539, 2006.

(Gheusi, Caccia, J.-L., Bénech, B., and Klaus, V.: Space-time description of nonstationary trapped lee wave using ST radars, aircraft and constant volume balloons during the PYREX experiment, J. Atmos. Sci., 54, 1821-1883, 1997. 
Cadet, D., Ovarlez, H., and Ovarlez, J.: Superpressure balloon flights in the tropical boudary layer, J. Appl. Meteor., 14, 14781484, 1975.

Cadet, D., Ovarlez, H., and Sommeria, G.: The BALSAMINE experiment during the summer MONEX, B. Am. Meteorol. Soc., 62, 381-388, 1981.

Courtier, P., Freydier, C., Geleyn, J., Rabier, F., and Rochas, M.: The ARPEGE project at Météo France, Atmospheric Models, Workshop on Numerical Methods, Reading, UK, 2, 193-231, 1991.

Cros, B., Durand, P., Cachier, H., Drobinski, P., Frejafon, E., Kottmeier, C., Perros, P., Peuch, V.-H., Ponche, J., Robin, D., Saïd, F., G., T., and Wortham, H.: The ESCOMPTE program: an overview, Atmos. Res., 69, 241-279, 2004.

Cuesta, J., Eremenko, M., Liu, X., Dufour, G., Cai, Z., Höpfner, M., von Clarmann, T., Sellitto, P., Foret, G., Gaubert, B., Beekmann, M., Orphal, J., Chance, K., Spurr, R., and Flaud, J.-M.: Satellite observation of lowermost tropospheric ozone by multispectral synergism of IASI thermal infrared and GOME-2 ultraviolet measurements over Europe, Atmos. Chem. Phys., 13, 9675-9693, doi:10.5194/acp-13-9675-2013, 2013.

Dentener, F., Stevenson, D., Cofala, J., Mechler, R., Amann, M., Bergamaschi, P., Raes, F., and Derwent, R.: The impact of air pollutant and methane emission controls on tropospheric ozone and radiative forcing: CTM calculations for the period 1990 2030, Atmos. Chem. Phys., 5, 1731-1755, doi:10.5194/acp-51731-2005, 2005.

Deshler, T., Mercer, J., Smit, H., Stuebi, R., Levrat, G., Johnson, B., Oltmans, S., Kivi, R., Thompson, A., Witte, J., Davies, J., Schmidlin, F., Brothers, G., and Sasaki, T.: Atmospheric comparison of electrochemical cell ozonesondes from different manufacturers, and with different cathode solution strengths: The Balloon Experiment on Standards for Ozonesondes, J. Geophys. Res., 113, D04307, doi:10.1029/2007JD008975, 2008.

Di Biagio, C., Doppler, L., Gaimoz, C., Grand, N., Ancellet, G., Raut, J.-C., Beekmann, M., Borbon, A., Sartelet, K., Attié, J.-L., Ravetta, F., and Formenti, P.: Continental pollution in the western Mediterranean basin: vertical profiles of aerosol and trace gases measured over the sea during TRAQA 2012 and SAFMED 2013, Atmos. Chem. Phys., 15, 9611-9630, doi:10.5194/acp-15-96112015, 2015.

Doerenbecher, A., Basdevant, C., Drobinski, P., Durand, P., Fesquet, C., Bernard, F., Cocquerez, P., Verdier, N., and Vargas, A.: Low atmosphere drifting balloons: platforms for environment monitoring and forecast improvement, B. Am. Meteorol. Soc., 97, 1583-1599, doi:10.1175/BAMS-D-14-00182.1, 2016.

Draxler, R. and Rolph, G.: HYSPLIT (HYbrid Single-Particle Lagrangian Integrated Trajectory) Model access via NOAA ARL READY Website, available at: http://www.arl.noaa.gov/ HYSPLIT.php (last access: 21 November 2016), NOAA Air Resources Laboratory, College Park, MD, USA, 2014.

Drobinski, P., Flamant, C., Dusek, J., Flamant, P., and Pelon, J.: Observational evidence and modelling of an internal hydraulic jump at the atmospheric boundary-layer top during a tramontane event, Bound.-Lay. Meteorol., 98, 497-515, 2001.

Durand, P., Druilhet, A., Bénech, B., and Hammam, A.: Mean and turbulent structure of a non-homogeneous boundary layer: experimental study of two local winds during AUTAN 84, Annal. Geophys., 11, 502-517, 1993.
El Amraoui, L., Attié, J.-L., Semane, N., Claeyman, M., Peuch, V.H., Warner, J., Ricaud, P., Cammas, J.-P., Piacentini, A., Josse, B., Cariolle, D., Massart, S., and Bencherif, H.: Midlatitude stratosphere - troposphere exchange as diagnosed by MLS $\mathrm{O}_{3}$ and MOPITT CO assimilated fields, Atmos. Chem. Phys., 10, 2175-2194, doi:10.5194/acp-10-2175-2010, 2010.

El Amraoui, L., Attié, J.-L., Ricaud, P., Lahoz, W. A., Piacentini, A., Peuch, V.-H., Warner, J. X., Abida, R., Barré, J., and Zbinden, R.: Tropospheric CO vertical profiles deduced from total columns using data assimilation: methodology and validation, Atmos. Meas. Tech., 7, 3035-3057, doi:10.5194/amt-73035-2014, 2014.

Ethé, C., Basdevant, C., Sadourny, R., Appu, K., Harenduprakash, L., Sarode, P., and Viswanathan, G.: Air mass motion, temperature and humidity over the Arabian Sea and western Indian Ocean during the INDOEX intensive phase, as obtained from a set of superpressure drifting balloons, J. Geophys. Res., 107, 8023, doi:10.1029/2001JD001120, 2002.

GAW ASOPOS panel: Quality assurance and quality control for ozonesonde measurements in GAW - GAW Report no. 201, World Meteorological Organization, Geneva, Switzerland, available at: http://www.wmo.int/pages/prog/arep/gaw/documents/ GAW_201.pdf (last access: 21 November 2016), 2011.

Gheusi, F.: Radiosonde - TRAQA, Sausset-les-Pins, doi:10.6096/MISTRALS-ChArMEx.764, https://doi.org/10 6096/MISTRALS-ChArMEx.764, 2012a.

Gheusi, F.: Ozone BPCL - LA - TRAQA - Sausset les Pins, doi:10.6096/MISTRALS-ChArMEx.765, https://doi.org/ 10.6096/MISTRALS-ChArMEx.765, 2012b.

Gheusi, F.: BLPB Ozone ADRIMED (Minorca), doi:10.6096/MISTRALS-ChArMEx.1450, https://doi.org/ 10.6096/MISTRALS-ChArMEx.1450, 2016a.

Gheusi, F.: BLPB Ozone SAFMED SOP-1 (Levant), doi:10.6096/MISTRALS-ChArMEx.1451, https://doi.org/ 10.6096/MISTRALS-ChArMEx.1451, 2016b.

Gheusi, F.: Radiosounding ozone ADRIMED (Minorca), doi:10.6096/MISTRALS-ChArMEx.1452, https://doi.org/ 10.6096/MISTRALS-ChArMEx.1452, $2016 \mathrm{c}$.

Gheusi, F.: Radiosounding ozone SAFMED SOP-1 (Levant), doi:10.6096/MISTRALS-ChArMEx.1453, https: //doi.org/10.6096/MISTRALS-ChArMEx.1453, 2016d.

Gheusi, F.: Surface ozone Minorca (ADRIMED), doi:10.6096/MISTRALS-ChArMEx.1454, https://doi.org/ 10.6096/MISTRALS-ChArMEx.1454, $2016 \mathrm{e}$.

Gheusi, F.: Surface ozone Levant (SAFMED SOP-1), doi:10.6096/MISTRALS-ChArMEx.1455, https://doi.org/ 10.6096/MISTRALS-ChArMEx.1455, 2016f.

Gheusi, F.: BLPB ozonesonde ground test May 2012 (Toulouse), doi:10.6096/MISTRALS-ChArMEx.1456, https://doi.org/10.6096/MISTRALS-ChArMEx.1456, 2016g.

Gheusi, F.: Ozonesonde in pulse mode preliminary test (Toulouse, May 2011), doi:10.6096/MISTRALS-ChArMEx.1458, https:// doi.org/10.6096/MISTRALS-ChArMEx.1458, $2016 \mathrm{~h}$.

Gheusi, F.: BLPB ozonesonde flowrate test (Toulouse, October 2012), doi:10.6096/MISTRALS-ChArMEx.1459, https:// doi.org/10.6096/MISTRALS-ChArMEx.1459, $2016 \mathrm{i}$.

Gheusi, F., Ravetta, F., Delbarre, H., Tsamalis, C., Chevalier-Rosso, A., Leroy, C., Augustin, P., Delmas, R., Ancellet, G., Athier, G., Bouchou, P., Campistron, B., Cousin, J.-M., Fourmentin, M., and 
Meyerfeld, Y.: Pic 2005, a field campaign to investigate lowtropospheric ozone variability in the Pyrenees, Atmos. Res., 101, 640-665, doi:10.1016/j.atmosres.2011.04.014, 2011.

Gifford, F.: A simultaneous Lagrangian-Eulerian turbulence experiment, Mon. Weather Rev., 83, 293-301, 1955.

Guenther, A., Hewitt, C. N., Erickson, D., Fall, R., Geron, C., Graedel, T., Harley, P., Klinger, L., Lerdau, M., McKay, W. A., Pierce, T., Scholes, B., Steinbrecher, R., Tallamraju, R., Taylor, J., and Zimmerman, P.: A global model of natural volatile organic compound emissions, J. Geophys. Res.-Atmos., 100, 8873-8892, 1995.

Kaiser, J. W., Heil, A., Andreae, M. O., Benedetti, A., Chubarova, N., Jones, L., Morcrette, J.-J., Razinger, M., Schultz, M. G., Suttie, M., and van der Werf, G. R.: Biomass burning emissions estimated with a global fire assimilation system based on observed fire radiative power, Biogeosciences, 9, 527-554, doi:10.5194/bg-9-527-2012, 2012.

Kalabokas, P. D., Cammas, J.-P., Thouret, V., Volz-Thomas, A., Boulanger, D., and Repapis, C. C.: Examination of the atmospheric conditions associated with high and low summer ozone levels in the lower troposphere over the eastern Mediterranean, Atmos. Chem. Phys., 13, 10339-10352, doi:10.5194/acp-1310339-2013, 2013.

Kalabokas, P., Thouret, V., J.-P., C., Volz-Thomas, A., Boulanger, D., and Repapis, C.: The geographical distribution of meteorological parameters associated with high and low summer ozone levels in the lower troposphere and the boundary layer over the eastern Mediterranean (Cairo case), Tellus B, 67, 67, 27853, doi:10.3402/tellusb.v67.27853, 2015.

Koffi, E., Georgelin, M., Bénech, B., and Richard, E.: Trapped lee waves observed during PYREX by constant volume balloons: comparison with Meso-NH simulations, J. Atmos. Sci., 57, 2007-2021, 2000.

Komhyr, W.: Electrochemical concentration cells for gas analysis, Ann. Géophys., 25, 203-210, 1969.

Kuenen, J., Denier van der Gon, H., Visschedijk, A., Van der Brugh, H., and Van Gijlswijk, R.: MACC European emission inventory for the years 2003-2007, TNO-report TNO-060-UT-201100588, Utrecht, 2011.

Legain, D., Bousquet, O., Douffet, T., Tzanos, D., Moulin, E., Barrie, J., and Renard, J.-B.: High-frequency boundary layer profiling with reusable radiosondes, Atmos. Meas. Tech., 6, 2195 2205, doi:10.5194/amt-6-2195-2013, 2013.

Lesouef, D., Gheusi, F., Chazette, P., Delmas, R., and Sanak, J.: Low tropospheric layers over Reunion Island in lidar-derived observations and a high-resolution model, Bound.-Lay. Meteorol., 149, 425-453, doi:10.1007/s10546-013-9851-9, 2013.

Mallet, M., Dulac, F., Formenti, P., Nabat, P., Sciare, J., Roberts, G., Pelon, J., Ancellet, G., Tanré, D., Parol, F., Denjean, C., Brogniez, G., di Sarra, A., Alados-Arboledas, L., Arndt, J., Auriol, F., Blarel, L., Bourrianne, T., Chazette, P., Chevaillier, S., Claeys, M., D’Anna, B., Derimian, Y., Desboeufs, K., Di Iorio, T., Doussin, J.-F., Durand, P., Féron, A., Freney, E., Gaimoz, C., Goloub, P., Gómez-Amo, J. L., Granados-Muñoz, M. J., Grand, N., Hamonou, E., Jankowiak, I., Jeannot, M., Léon, J.-F., Maillé, M., Mailler, S., Meloni, D., Menut, L., Momboisse, G., Nicolas, J., Podvin, T., Pont, V., Rea, G., Renard, J.-B., Roblou, L., Schepanski, K., Schwarzenboeck, A., Sellegri, K., Sicard, M., Solmon, F., Somot, S., Torres, B., Totems, J., Triquet, S.,
Verdier, N., Verwaerde, C., Waquet, F., Wenger, J., and Zapf, P.: Overview of the Chemistry-Aerosol Mediterranean Experiment/Aerosol Direct Radiative Forcing on the Mediterranean Climate (ChArMEx/ADRIMED) summer 2013 campaign, Atmos. Chem. Phys., 16, 455-504, doi:10.5194/acp-16-455-2016, 2016.

Mao, H., Talbot, R., Troop, D., Johnson, R., Businger, S., and Thompson, A.: Smart balloon observations over the North Atlantic: ozone data analysis and modelling, J. Geophys. Res., 111, D23S56, doi:10.1029/2005JD006507, 2006.

Morris, G. A., Thompson, A. M., Pickering, K. E., Chen, S., Bucsela, E. J., and Kucera, P. A.: Observations of ozone production in a dissipating tropical convective cell during TC4, Atmos. Chem. Phys., 10, 11189-11208, doi:10.5194/acp-10-11189-2010, 2010.

Nabat, P., Somot, S., Mallet, M., Chiapello, I., Morcrette, J. J., Solmon, F., Szopa, S., Dulac, F., Collins, W., Ghan, S., Horowitz, L. W., Lamarque, J. F., Lee, Y. H., Naik, V., Nagashima, T., Shindell, D., and Skeie, R.: A 4-D climatology (1979-2009) of the monthly tropospheric aerosol optical depth distribution over the Mediterranean region from a comparative evaluation and blending of remote sensing and model products, Atmos. Meas. Tech., 6, 1287-1314, doi:10.5194/amt-6-1287-2013, 2013.

Peuch, V.-H., Amodei, M., Barthet, T., Cathala, M. L., Michou, M., and Simon, P.: MOCAGE, MOdèle de Chimie Atmosphérique à Grande Echelle, Proceedings of Météo-France workshop on atmospheric modelling, Toulouse, France, 33-36, 1999.

Piguet, B. and Perrin, T.: ATR Core in-situ measurements TRAQA, doi:10.6096/MISTRALS-ChArMEx.998, https://doi. org/10.6096/MISTRALS-ChArMEx.998, 2013.

Renard, J.-B., Dulac, F., Berthet, G., Lurton, T., Vignelles, D., Jégou, F., Tonnelier, T., Jeannot, M., Couté, B., Akiki, R., Verdier N., Mallet, M., Gensdarmes, F., Charpentier, P., Mesmin, S., Duverger, V., Dupont, J.-C., Elias, T., Crenn, V., Sciare, J., Zieger, P., Salter, M., Roberts, T., Giacomoni, J., Gobbi, M., Hamonou, E., Olafsson, H., Dagsson-Waldhauserova, P., Camy-Peyret, C., Mazel, C., Décamps, T., Piringer, M., Surcin, J., and Daugeron, D.: LOAC: a small aerosol optical counter/sizer for ground-based and balloon measurements of the size distribution and nature of atmospheric particles - Part 1: Principle of measurements and instrument evaluation, Atmos. Meas. Tech., 9, 1721-1742, doi:10.5194/amt-9-1721-2016, 2016a.

Renard, J.-B., Dulac, F., Berthet, G., Lurton, T., Vignelles, D., Jégou, F., Tonnelier, T., Jeannot, M., Couté, B., Akiki, R., Verdier, N., Mallet, M., Gensdarmes, F., Charpentier, P., Mesmin, S., Duverger, V., Dupont, J.-C., Elias, T., Crenn, V., Sciare, J., Zieger, P., Salter, M., Roberts, T., Giacomoni, J., Gobbi, M., Hamonou, E., Olafsson, H., Dagsson-Waldhauserova, P., Camy-Peyret, C., Mazel, C., Décamps, T., Piringer, M., Surcin, J., and Daugeron, D.: LOAC: a small aerosol optical counter/sizer for ground-based and balloon measurements of the size distribution and nature of atmospheric particles - Part 2: First results from balloon and unmanned aerial vehicle flights, Atmos. Meas. Tech., 9, 3673 3686, doi:10.5194/amt-9-3673-2016, 2016 b.

Simon, V., Dumergues, L., Ponche, J.-L., and Torres, L.: The biogenic volatile organic compounds emission inventory in France: Application to plant ecosystems in the BerreMarseilles area (France), Sci. Total Environ., 372, 164-182, doi:10.1016/j.scitotenv.2006.08.019, 2006. 
Smit, H., Straeter, W., Johnson, B., Oltmans, S., Davies, J., Tarasick, D., Hoegger, B., Stuebi, R., Schmidlin, F., Northam, T., Thompson, A., Witte, J., Boyd, I., and Posny, F.: Assessment of the performance of ECC-ozonesondes under quasi-flight conditions in the environmental simulation chamber: Insights from the Juelich Ozone Sonde Intercomparison Experiment (JOSIE), J. Geophys. Res., 112, D19306, doi:10.1029/2006JD007308, 2007.

Staehelin, J.: Global atmospheric ozone monitoring, Bull. World Meteor. Org., 57, 45-54, 2008.
Stein, A., Draxler, R., Rolph, G., Stunder, B., Cohen, M., and Ngan, F.: NOAA's HYSPLIT atmospheric transport and dispersion modeling system, B. Am. Meteorol. Soc., 96, 2059-2077, doi:10.1175/BAMS-D-14-00110.1, 2015.

Vömel, H. and Diaz, K.: Ozone sonde cell current measurements and implications for observations of near-zero ozone concentrations in the tropical upper troposphere, Atmos. Meas. Tech., 3, 495-505, doi:10.5194/amt-3-495-2010, 2010. 